https://doi.org/10.5194/tc-2021-116

Preprint. Discussion started: 30 April 2021

(C) Author(s) 2021. CC BY 4.0 License.

\title{
An empirical algorithm to map perennial firn aquifers, ice slabs, and perched firn aquifers within the Greenland Ice Sheet using satellite L-band microwave radiometry
}

\author{
Julie Z. Miller1,2, Riley Culberg3, David G. Long4, Christopher A. Shuman5, \\ Dustin M. Schroeder ${ }^{3,6}$, Mary J. Brodzik1,7 \\ ${ }^{1}$ Cooperative Institute for Research in Environmental Sciences, University of Colorado, Boulder, Colorado, USA \\ ${ }^{2}$ Earth Science and Observation Center, University of Colorado, Boulder, Colorado, USA \\ ${ }^{3}$ Department of Electrical Engineering, Stanford University, Stanford, California, USA \\ ${ }^{4}$ Department of Electrical and Computer Engineering, Brigham Young University, Provo, Utah, USA \\ ${ }^{5}$ University of Maryland, Baltimore County, Joint Center for Earth Systems Technology at Code 615, \\ Cryospheric Sciences Laboratory NASA Goddard Space Flight Center, Greenbelt, Maryland, USA \\ ${ }^{6}$ Department of Geophysics, Stanford University, Stanford, CA, USA \\ ${ }^{7}$ National Snow and Ice Data Center, University of Colorado, Boulder, Colorado, USA \\ Correspondence to: izmiller.research@gmail.com
}

\section{Abstract}

Perennial firn aquifers are subsurface meltwater reservoirs formed from a water-saturated firn layer. They have been observed within the percolation facies of glaciated regions experiencing intense seasonal surface melting and high snow accumulation. Widespread perennial firn aquifers have been identified within the Greenland Ice Sheet (GrIS) via field expeditions, airborne ice-penetrating radar surveys, and satellite microwave sensors. In contrast, ice slabs are nearly-continuous ice layers that form on spatial scales of kilometers as a result of surface and subsurface watersaturated snow and firn layers sequentially refreezing following multiple melting seasons. They have been observed within the percolation facies of glaciated regions experiencing intense seasonal surface melting, but in areas where snow accumulation is at least $\sim 25 \%$ lower as compared to perennial firn aquifer areas. Widespread ice slabs have recently been identified within the GrIS via field expeditions and airborne ice-penetrating radar surveys, specifically in areas where perennial firn aquifers typically do not form. However, ice slabs have yet to be inferred from space. Together, these two ice sheet features represent distinct, but related, sub-facies within the broader percolation facies of the GrIS that can be defined primarily by differences in snow accumulation, which influences the englacial hydrology and thermal characteristics of firn layers at depth.

Here, for the first time, we use enhanced-resolution vertically-polarized L-band brightness temperature $\left(T_{V}^{B}\right)$ imagery (2015-2019) generated using observations collected over the GrIS by NASA's Soil Moisture Active Passive (SMAP) satellite to map both perennial firn aquifer and ice slab areas as a continuous system over the percolation facies. We also map 'perched' firn aquifer areas, which we define as areas where shallow water-saturated firn layers transiently form on top of buried ice slabs, or other semi-impermeable layers within the snow and firn. An empirical algorithm 
https://doi.org/10.5194/tc-2021-116

Preprint. Discussion started: 30 April 2021

(C) Author(s) 2021. CC BY 4.0 License.

previously developed to map the extent of Greenland's perennial firn aquifers via fitting exponentially decreasing temporal L-band signatures to a set of sigmoidal curves is recalibrated to also map the extent of ice slab and perched firn aquifer areas using airborne ice-penetrating radar surveys collected by NASA's Operation Ice Bridge (OIB) campaigns (2010-2017). Our SMAP-derived maps show that between 2015 and 2019, perennial firn aquifer areas extended over $\sim 64,000 \mathrm{~km}^{2}$, ice slab areas extended over $\sim 76,000 \mathbf{k m}^{2}$, and perched firn aquifer areas extended over $\sim 37,000 \mathbf{k m}^{2}$. Combined together, these three sub-facies are the equivalent of $\sim 24 \%$ of the percolation facies of the GrIS. As Greenland's climate continues to warm, and seasonal surface melting increases in extent, intensity, and duration, quantifying the possible rapid expansion of each of these sub-facies using satellite L-band microwave radiometry has significant implications for understanding ice sheet-wide variability in englacial firn hydrology resulting in meltwater-induced hydrofracturing and accelerated ice flow as well as high-elevation run-off that can impact the mass balance and stability of the GrIS.

\section{Introduction}

The recent launch of several satellite L-band microwave radiometry missions by NASA (Aquarius mission, Levine, et al., 2007; Soil Moisture Active Passive (SMAP) mission, Entekhabi et al., 2010) and ESA (Soil Moisture and Ocean Salinity (SMOS), Kerr et al., 2010) has provided a new Earth-observation tool capable of detecting stored meltwater tens of meters to kilometers beneath the surface of ice sheets. Jezek et al. (2015) recently demonstrated that in the high-elevation ( 3500 m.a.s.l.) dry snow facies of the Antarctic Ice Sheet, meltwater stored in subglacial Lake Vostok can be detected $\sim 4000 \mathrm{~m}$ beneath the ice sheet surface. Subglacial lakes represent radiometrically cold subsurface meltwater reservoirs. Upwelling L-band emissions from the radiometrically warm bedrock underlying the subglacial lakes are effectively blocked by high reflectivity and attenuation at the interface between bedrock and the overlying lake bottom. This results in a lower observed microwave brightness temperature $\left(T^{B}\right)$ at the ice sheet surface as compared to other dry snow facies areas where bedrock contributes to L-band emissions depth-integrated over the entire ice sheet thickness.

Similar to subglacial lakes, perennial firn aquifers also represent radiometrically cold subsurface meltwater reservoirs (Miller et al., 2020) formed from a $\sim 4$ m-25 m thick water-saturated firn layer (Koenig et al., 2014; Montgomery et al., 2017; Chu et al., 2018). They have been observed via field expeditions and airborne ice-penetrating radar surveys in the lower-elevation $(<\sim 2000$ m.a.s.l.) percolation facies of the Greenland Ice Sheet ( $\mathrm{GrIS}$ ), at depths from between $\sim \mathrm{m}$ and $40 \mathrm{~m}$ beneath the ice sheet surface (Miège

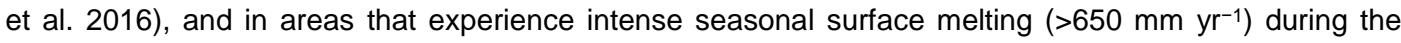
melting season and high snow accumulation (>800 $\mathrm{mm} \mathrm{yr}^{-1}$ ) during the freezing season (Forster et al., 2014). High snow accumulation in perennial firn aquifer areas thermally insulates water-saturated firn layers from the cold atmosphere allowing seasonal meltwater to be stored in liquid form if the overlying seasonal 
https://doi.org/10.5194/tc-2021-116

Preprint. Discussion started: 30 April 2021

(C) Author(s) 2021. CC BY 4.0 License.

78

79

80

81

82

83

84

85

86

87

88

89

90

91

92

93

94

95

96

97

98

99

100

101

102

103

104

105

106

107

108

109

110

111

112

113

114

volumetric fraction of meltwater stored within the pore space of Greenland's perennial firn aquifers just prior to melt onset ranges from between $\sim 10 \%$ and $25 \%$, which limits the upward propagation of electromagnetic energy from greater depths within the ice sheet. Large volumetric fractions of meltwater within the firn pore space results in high reflectivity and attenuation at the interface between water-saturated firn layers and the overlying refrozen firn layers, and between glacial ice or a semi-impermeable layer and the overlying water-saturated firn layers. Upwelling L-band emissions from deeper glacial ice and the underlying bedrock are effectively blocked.

While perennial firn aquifers are radiometrically cold, the slow refreezing of deeper firn layers saturated with large volumetric fractions of meltwater represents a significant source of latent heat that is continuously released throughout the freezing season. Refreezing of seasonal meltwater by the descending winter cold wave (Pfeffer et al., 1991), and the subsequent formation of embedded ice structures (i.e., horizontally-oriented ice layers and ice lenses, and vertically-oriented ice pipes; Benson et al., 1960; Humphrey et al., 2012; Harper et al., 2012) within the upper snow and firn layers represents a secondary source of latent heat. These heat sources help maintain meltwater at depth. Perennial firn aquifer areas are radiometrically warmer than other percolation facies areas where the single source of latent heat is via refreezing of seasonal meltwater. This results in a higher observed $T^{B}$ at the ice sheet surface during the freezing season as compared to other percolation facies areas where seasonal meltwater is fully refrozen and stored exclusively as embedded ice.

Many open questions remain about Greenland's perennial firn aquifers, regarding initial formation, extent, depth, flow characteristics, timescales of refreezing and/or englacial drainage, and connections to the subglacial hydrological system. Seasonal surface melting over the GrIS has increased in extent, intensity, and duration since the beginning of the satellite era (Steffen et al., 2004; Tedesco e al., 2008; Tedesco et al., 2011; Nghiem et al., 2012; Tedesco et al., 2016; Tedesco and Fettweis, 2020; Cullather et al., 2020). If this trend continues (Franco et al., 2013; Noël et al., 2021), subsequent increases in the volume of meltwater stored within Greenland's perennial firn aquifers will increase the possibility of crevasse-deepening via meltwater-induced hydrofracturing (Alley et al., 2005; van der Veen, 2007), especially if crevasse fields laterally expand into perennial firn aquifer areas as a result of accelerated ice flow (Colgan et al., 2016). Meltwater-induced hydrofracturing is an important component of supraglacial lake drainage during the melting season (Das et al., 2008; Stevens et al., 2015) leading to at least temporary accelerated flow velocities (Zwally et al., 2002; Joughin et al., 2013; Moon et al., 2014) and mass balance changes (Joughin et al., 2008). Greenland's firn perennial aquifers may also support meltwater-induced hydrofracturing, even during the freezing season (Poinar et al., 2017; 2019).

Recently, mapping the extent of Greenland's perennial firn aquifers from space was demonstrated using satellite L-band microwave radiometry (Miller et al., 2020). Exponentially decreasing temporal L-band signatures observed in enhanced-resolution vertically-polarized L-band brightness temperature $\left(T_{V}^{B}\right)$ imagery (2015-2016) generated using observations collected over the GrIS by the microwave radiometer on the SMAP satellite (Brodzik et al., 2019) were correlated with a single year of perennial firn aquifer 
https://doi.org/10.5194/tc-2021-116

Preprint. Discussion started: 30 April 2021

(C) Author(s) 2021. CC BY 4.0 License.

115 detections (2016) identified via the Center for Remote Sensing of Ice Sheets (CReSIS) Multi-Channel

116 Coherent Radar Depth Sounder (MCoRDS) flown by NASA's Operation Ice Bridge (OIB) campaigns (Miège

117 et al. 2016; Rodriguez-Morales et al, 2014). An empirical algorithm to map extent was developed by fitting

118 temporal L-band signatures to a set of sigmoidal curves derived from the continuous logistic model.

119 The relationship between the radiometric, and thus the physical, temperature of perennial firn 120 aquifer areas, as compared to other percolation facies areas, forms the basis of the empirical algorithm. 121 Miller et al. (2020) hypothesized that the dominant control on the relatively slow exponential rate of $T_{V}^{B}$ 122 decrease over perennial firn aquifer areas is physical temperature versus depth. L-band emissions from 123 the radiometrically warm upper snow and firn layers decrease during the freezing season as embedded ice 124 structures slowly refreeze at increased depths below the ice sheet surface. In the percolation facies, 125 refreezing of seasonal meltwater results in the formation of an intricate network of embedded ice structures 126 that are large ( $\sim 10-100 \mathrm{~cm}$ long, $\sim 10-20 \mathrm{~cm}$ wide; Jezek et al., 1994) relative to the L-band wavelength 127 ( 21 cm). Embedded ice structures induce strong volume scattering (Rignot et al., 1993; Rignot 1995) that 128 decreases $T^{B}$ (Zwally, 1977; Swift et al. 1985; Jezek et al., 2018).

$129 \quad$ Ice slabs are $~ 1 \mathrm{~m}-16 \mathrm{~m}$ thick nearly-continuous ice layers that form on spatial scales of kilometers 130 as a result of surface and subsurface water-saturated snow and firn layers sequentially refreezing following 131 multiple melting seasons (Machguth et al., 2016; McFerrin et al., 2019). Over time, they become dense low132 permeability solid-ice layers overlying deeper permeable firn layers. Similar to perennial firn aquifers, ice 133 slabs have been observed via field expeditions and ice-penetrating airborne radar surveys in the lower134 elevation (< 2000 m.a.s.I.) percolation facies of the GrIS. They form at depths from between $\sim 1 \mathrm{~m}$ and 20 $135 \mathrm{~m}$ beneath the ice sheet surface. Particularly in areas that experience intense seasonal surface melting 136 (>600 mm $\mathrm{yr}-1)$ during the melting season, and lower snow accumulation $(<600 \mathrm{~mm} \mathrm{yr}-1)$ during the 137 freezing season as compared to perennial firn aquifer areas (McFerrin et al., 2019). Lower snow 138 accumulation in ice slab areas results in a seasonal snow layer that is insufficiently thick to thermally 139 insulate water-saturated firn layers and seasonal meltwater is instead stored as embedded ice. Refreezing 140 of seasonal meltwater by the descending winter cold wave, and the subsequent formation of ice slabs as 141 well as other embedded ice structures within the upper snow and firn layers is the single source of latent 142 heat in ice slab areas. While ice slab areas are radiometrically warmer than other percolation facies areas 143 with a lower volumetric fraction of embedded ice, they are radiometrically colder than perennial firn aquifer

144 areas. This results in a lower observed $T^{B}$ at the ice sheet surface during the freezing season.

145 Consistent with recent seasonal surface melting trends, meltwater run-off has accelerated to 146 become the dominant mass loss mechanism over the GrIS (van den Broeke et al., 2016). However, 147 significant uncertainty remains in meltwater run-off estimates in the percolation facies as a result of the lack 148 of knowledge of heterogeneous infiltration processes within the snow and firn layers (Pfeffer and Humphrey, 149 1996), the depths to which meltwater can descend beneath the ice sheet surface (Humphrey et al., 2012), 150 and the formation of englacial firn hydrological features (Benson et al., 1960; Humphrey et al., 2012; Forster 151 et al., 2014), especially ice layers and ice slabs (Machguth et al., 2016, McFerrin et al., 2019; Culberg et 
https://doi.org/10.5194/tc-2021-116

Preprint. Discussion started: 30 April 2021

(C) Author(s) 2021. CC BY 4.0 License.

152 al., 2021). A notable example of this lack of knowledge is the identification by Forster et al., (2014) of 153 widespread perennial firn aquifers within the percolation facies of the GrIS via airborne ice-penetrating radar 154 surveys collected by NASA's OIB campaigns (2010-2014; Rodriguez-Morales et al, 2014) that store large volumes ( 140 Gt; Koenig et al., 2014) of meltwater that was previously unknown. The mapped extent (2010-2014) shown in Forster et al., (2014) can be distinctly observed in 1978 enhanced resolution Kuband radar backscatter imagery (Long and Drinkwater, 1994) collected by the radar scatterometer on NASA's first Earth-observing satellite - the Seasat-A mission (Jones et al., 1982). This suggests that Greenland's perennial firn aquifers have likely existed undetected in the deeper firn layers of the percolation facies for decades. Meltwater storage in both solid (i.e., embedded ice structures) and liquid (i.e., perennial firn and perched firn aquifers) form can buffer meltwater run-off in the percolation facies (Harper et al., 2012). However, the formation of near-surface ice layers and ice slabs reduces the pore space within the upper snow and firn layers and facilitates lateral meltwater flow with minimum vertical percolation into the deeper firn layers, thus enhancing meltwater run-off downslope towards the periphery. Lateral meltwater flow across ice layers overlying deeper permeable firn layers was first postulated by Müller (1962). The theory was then further developed by Pfeffer et al., (1991) as an end-member case for meltwater run-off, with the other end member case being lateral meltwater flow across superimposed ice in the wet snow facies and/or across glacial ice in the ablation facies. McFerrin et al., (2019) recently identified widespread near-surface ice slabs within the percolation facies of the GrIS via airborne ice-penetrating radar surveys collected by NASA's OIB campaigns (2010-2014; Rodriguez-Morales et al, 2014). Lateral meltwater flow and high-elevation ( 1850 m.a.s.I) meltwater run-off across the identified ice slabs was also observed in visible satellite imagery collected by the NASA-USGS Landsat 7 mission (e.g. Goward et al., 2001). This was also observed during the anomalous 2012 melting season (McFerrin et al., 2019) during which seasonal surface melting extended over $~ 99 \%$ of the GrIS (Nghiem et al., 2012)

In this study, we use enhanced-resolution L-band $T_{V}^{B}$ imagery (2015-2019) generated using observations collected over the GrIS by the microwave radiometer on the SMAP satellite (Brodzik et al., 2019) to map ice sheet-wide englacial firn hydrological features within the percolation facies. First, we adapt our empirical algorithm to map the extent of Greenland's perennial firn aquifers (Miller et al., 2020). We correlate exponentially decreasing temporal L-band signatures with five years of perennial firn aquifer detections (2010-2014) identified via the CReSIS Accumulation Radar (AR) flown by NASA's OIB campaigns (Miège et al. 2016), and three years of additional detections (2015-2017) more recently identified via MCoRDS (Miller et al., 2020). Next, we extend our empirical algorithm to also map the extent 183 of ice slab and perched firn aquifer areas. We identify distinct temporal L-band signatures in $T_{V}^{B}$ time series over ice slab detections (2010-2014) recently identified via AR (McFerrin et al., 2019). Similar to temporal L-band signatures over perennial firn aquifer areas, temporal L-band signatures over ice slab areas are exponentially decreasing during the freezing season, however, the rate of $T_{V}^{B}$ decrease is slightly more

187 rapid. We correlate these relatively rapidly exponentially decreasing temporal L-band signatures with five 188 
https://doi.org/10.5194/tc-2021-116

Preprint. Discussion started: 30 April 2021

(C) Author(s) 2021. CC BY 4.0 License.

(c) (i)

189 band signatures with AR- and MCoRDS-derived detections where perennial firn aquifer and ice slab areas

190 overlap. We identify these transitional areas as perched firn aquifer areas. We infer that, in these areas,

191 shallow water-saturated firn layers transiently form on top of buried ice slabs or other semi-impermeable

192 layers, such as spatially coherent melt layers that form in the higher elevations (> 2000 m.a.s.I.) of the

193 percolation facies and the dry snow facies that were recently identified via AR (Culberg et al., 2021).

194 Perched firn aquifers likely form during some melting seasons as a result of interannual variability in surface

195 melting and snow accumulation, and the formation of englacial firn hydrological features. Finally, we re-

196 calibrate the sigmoidal curves to map the extent of perennial firn aquifer, ice slab, and perched firn aquifer

197 areas over the percolation facies of the GrIS

198

199

\section{Methods}

\subsection{The Soil Moisture Active Passive (SMAP) Mission}

The key science objectives of NASA's SMAP mission (https://smap.jpl.nasa.gov/) are to map terrestrial soil moisture and freeze/thaw state over Earth's land surfaces from space. However, the global L-band $T^{B}$ observations collected by the SMAP satellite also have many cryospheric applications. Mapping ice sheetwide englacial firn hydrological features over Earth's polar ice sheets represents an interesting analog and an innovative extension of the science objectives. Measurements of moisture (i.e., defined in this study in terms of the volumetric fraction of meltwater within the upper snow and firn layers of the percolation facies) and freeze-thaw state (i.e., defined in this study in terms of the firn saturation parameter (see Section 2.4.3) and the refreezing rate parameter (see Section 2.4.4)) are critical to understanding the hydrospheric state over Earth's polar ice sheets. Perennial firn aquifers, ice slabs, and perched firn aquifers represent recently identified components of the hydrosphere that are capable of storing large volumes of meltwater in both solid and liquid form that can initiate meltwater-induced hydrofracturing and accelerated ice flow as well as high-elevation run-off, and impact the mass balance and stability of the GrIS. Critically, the majority of meltwater is stored at depths that only L-band satellite microwave sensors (i.e., radiometers, radar scatterometers, and synthetic aperture radars) are capable of detecting.

Previous and current satellite microwave radiometer, radar scatterometer, and synthetic aperture radar missions that operate in the frequency range between $37 \mathrm{GHz}$ (Ka-band) and $5.3 \mathrm{GHz}$ (C-band) have provided a multi-decadal (1978-present) record of multi-frequency $T^{B}$ and radar backscatter observations over Earth's polar ice sheets since the beginning of the satellite era. The most common geophysical parameter mapped over ice sheets using these observations is the extent of seasonal surface melting. The key difference between L-band and higher frequency satellite microwave sensors is penetration depth. When the snow and firn layers are saturated with meltwater during the melting season, the penetration depth of both L-band and higher frequency satellite microwave sensors is less than a meter. When surface and subsurface water-saturated snow and firn layers and embedded ice structures subsequently refreeze, the penetration depth of higher frequency satellite microwave sensors ranges from between centimeters 
https://doi.org/10.5194/tc-2021-116

Preprint. Discussion started: 30 April 2021

(C) Author(s) 2021. CC BY 4.0 License.

(i.e., ice layers, ice slabs, spatially coherent melt layers) or underlay the refrozen upper snow and firn layers of the percolation facies and descend to depths ranging from between $\sim 1 \mathrm{~m}$ and $40 \mathrm{~m}$ (Miège et al., 2016) beneath the ice sheet surface (i.e., perennial and perched firn aquifers). While the upper surface of stored meltwater in some perennial and perched firn aquifers may remain at depths that are shallow enough to be directly detected by C-band satellite microwave sensors, the mean depth just prior to melt onset ( 22 m; Miège et al., 2016) is too deep to be detected at this wavelength. L-band satellite microwave sensors can detect perennial firn aquifers from as much as an order of magnitude deeper than can be observed by Cband satellite microwave radiometers. Deep enough to directly detect the upper surface of stored meltwater over the entire depth range mapped by airborne ice-penetrating radar surveys over the GrIS.

\subsection{SMAP Enhanced-Resolution L-band $T^{B}$ Imagery}

NASA's SMAP satellite was launched 31 January 2015 and carries a microwave radiometer that operates at a frequency of $1.41 \mathrm{GHz}$ (L-band) (Enkentabi et al., 2010). It is currently collecting observations of vertically and horizontally-polarized $T^{B}$ over Greenland. The surface incidence angle is $\sim 40^{\circ}$, and the radiometric accuracy is $\sim 1.3 \mathrm{~K}$ (Piepmeier et al., 2017).

The Scatterometer Image Reconstruction (SIR) algorithm was developed to reconstruct coarse resolution satellite scatterometry imagery on a higher spatial resolution grid (Long et al., 1993; Early and Long, 2001). The SIR algorithm has been adapted for coarse resolution satellite microwave radiometry imagery (Long and Daum, 1998; Long and Brodzik, 2016; Long et al., 2019). The microwave radiometer form of the SIR algorithm (rSIR) exploits the measurement response function (MRF) for each observation, which is a smeared version of the antenna pattern. Using the overlapping MRFs, the rSIR algorithm reconstructs $T^{B}$ from the spatially filtered low-resolution sampling provided by the observations. In effect, it generates an MRF-deconvolved $T^{B}$ image. Combining multiple orbital passes increases the sampling density, which improves both the accuracy and resolution of SMAP enhanced-resolution $T^{B}$ imagery (Long et al., 2019).

Over Greenland, the rSIR algorithm combines satellite orbital passes that occur between 8 a.m. and 4 p.m. local time-of-day to reconstruct SMAP enhanced-resolution $T^{B}$ imagery twice-daily (i.e., morning and evening orbital pass interval, respectively). $T^{B}$ imagery is projected on a Northern Hemisphere $(\mathrm{NH})$ Equal-Area Scalable Earth Grid (EASE-Grid 2.0; Brodzik et al., 2012) at a $3.125 \mathrm{~km}$ rSIR grid cell spacing. The effective resolution for each grid cell is dependent on the number of observations used in the rSIR reconstruction and is coarser than the rSIR grid cell spacing. While the effective resolution of conventionally processed SMAP $T^{B}$ imagery posted on a $25 \mathrm{~km}$ grid is $\sim 30 \mathrm{~km}$, the effective resolution of SMAP enhancedresolution $T^{B}$ imagery posted on a $3.125 \mathrm{~km}$ grid is $\sim 18 \mathrm{~km}$, an improvement of $\sim 60 \%$ (Figs. 1; 2) (Long et al., 2020).

For our analysis of the percolation facies, we use SMAP enhanced-resolution $T_{V}^{B}$ imagery over the GrIS. Compared to the horizontally-polarized channel, the vertically-polarized channel exhibits decreased sensitivity to variability in the volumetric fraction of meltwater, which is attributed to reflection coefficient 
https://doi.org/10.5194/tc-2021-116

Preprint. Discussion started: 30 April 2021

(c) Author(s) 2021. CC BY 4.0 License.

(c) (i)

263 differences between channels (Miller et al., 2020). Using the vertically polarized channel also results in a

264 reduced chi-squared error statistic when fitting $T_{V}^{B}$ time series to the sigmoid function (see Section 2.4.5).

265 We construct $T_{V}^{B}$ imagery that alternate morning and evening orbital pass observations annually, beginning

266 and ending just prior to melt onset. The Greenland Ice Mapping Project (GIMP) Land Ice and Ocean

267 Classification Mask and Digital Elevation Model (Howat et al., 2014) are projected on a NH EASE-Grid 2.0

268 at a $3.125 \mathrm{~km}$ rSIR grid cell spacing. $T_{V}^{B}$ imagery between 1 April 2015 and 31 March 2019 are ice sheet-

269 masked, and an elevation for each rSIR grid cell is calculated.

270

\subsection{Airborne Ice-Penetrating Radar Surveys}

272 Miller et al., (2020) calibrated the empirical algorithm to map the extent of Greenland's perennial firn 273 aquifers by correlating a single year of exponentially decreasing temporal L-band signatures (2015-2016)

274 with coincident perennial firn aquifer detections (2016) identified via MCoRDS. Here, we extend and expand 275 the calibration of our adapted empirical algorithm to include four years of exponentially decreasing temporal 276 L-band signatures (2015-2019) correlated with eight years of perennial firn aquifer detections (2010-2017) 277 and five years of ice slab detections (2010-2014) identified via AR and MCoRDS (Fig. 1c). Our multi-year 278 calibration technique projects perennial firn aquifer and ice slab detections on three separate NH EASE279 Grids 2.0 at an rSIR grid cell spacing of $3.125 \mathrm{~km}$, consistent with the rSIR grid cell spacing of the SMAP 280 enhanced-resolution L-band $T_{V}^{B}$ imagery. Interannual variability is not resolved in this study, however, it will 281 be explored further in future work.

282 An advantage of the multi-year calibration technique as compared to the single-coincident year 283 calibration technique (Miller et al., 2020) is that it increases the number of rSIR grid cells that can be 284 assessed. It also provides repeat targets that can account for variability in the dielectric and geophysical 285 properties that seasonally influence the radiometric temperature and temporal L-band signatures in stable 286 perennial firn aquifer, ice slab, and perched firn aquifer areas. Uncertainty is introduced by correlating 287 exponentially decreasing temporal L-band signatures with AR- and MCoRDS-derived detections that are 288 not coincident in time. The multi-year calibration technique assumes the extent of each area remains stable, 289 which is not necessarily the case as climate extremes (Cullather et al., 2020) can influence each of these 290 sub-facies. The assumption of stability neglects boundary transitions in the extent of perennial firn aquifer 291 areas associated with refreezing of shallow water-saturated firn layers, englacial drainage of meltwater into 292 crevasses at the periphery (Poinar et al., 2017; Poinar et al, 2019), and transient upslope expansion 293 (Montgomery et al., 2017). Once formed, ice slabs are essentially permanent features within the upper 294 snow and firn layers of the percolation facies until they are compressed into glacial ice. However, they may 295 transition into superimposed ice at the lower boundary of ice slab areas or rapidly expand upslope, 296 particularly following extreme melting seasons (McFerrin et al., 2019). By our definition, perched firn 297 aquifers are transient features. Thus, we simply consider our mapped extent a high-probability area for the 298 preferential formation of each of these sub-facies within the broader percolation facies, with continued 299 presence dependent on seasonal surface melting and snow accumulation in subsequent years. 
https://doi.org/10.5194/tc-2021-116

Preprint. Discussion started: 30 April 2021

(c) Author(s) 2021. CC BY 4.0 License.
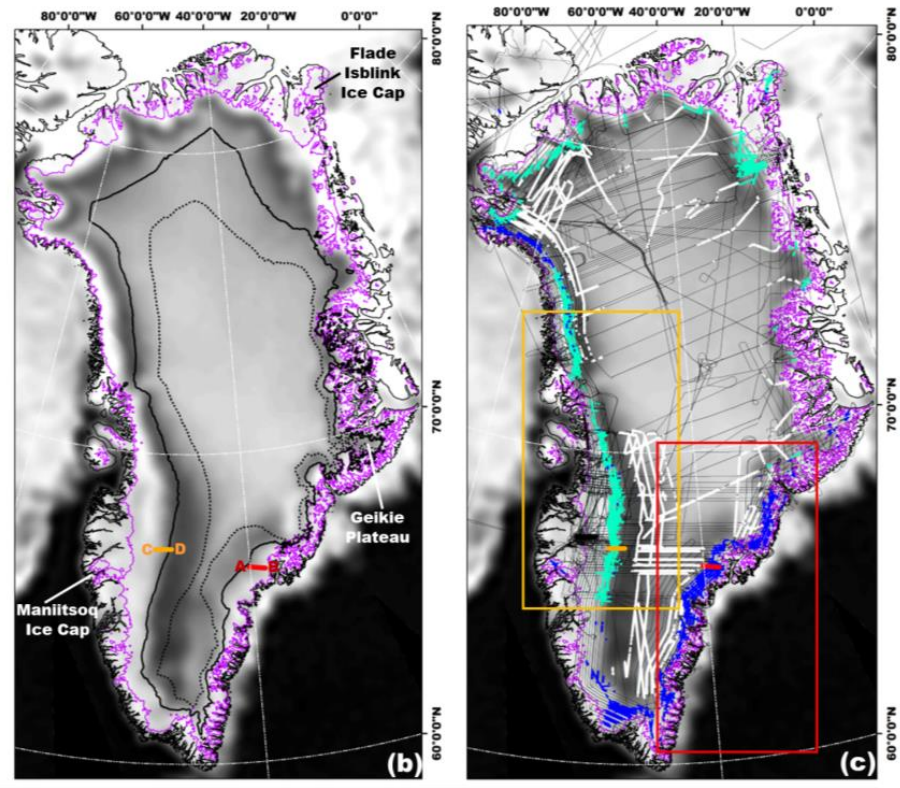

\section{Figure 1}

(a) Gridded (25 km), and (b) enhanced-resolution (3.125 km) L-band $T_{V}^{B}$ imagery generated using observations collected 15 April 2016 by the microwave radiometer on the SMAP satellite during the evening orbital pass interval over Greenland (Brodzik et al., 2019). The solid black line is the 2000 m.a.s.l. contour, and the black dotted line is the 2500 m.a.s.l. contour (Howat et al., 2014). The purple line is the ice sheet extent (Howat et al., 2014). The black peripheral line is the coast of Greenland and adjacent Ellesmere Island (Wessel and Smith, 1996). The whiter regions of higher $T_{V}^{B}$ over the high-elevation (> 2500 m.a.s.I.) interior are the dry snow facies. The darker grey regions of lower $T_{V}^{B}$ are the percolation facies, including ice slabs and perched firn aquifer areas. The whiter regions of higher $T_{V}^{B}$ over the coastal areas, peripheral ice caps (e.g., Maniitsoq and Flade Isblink) and nearby islands are perennial firn aquifers, superimposed or glacial ice, land, or spatially integrated $L$-band emissions. The whiter regions of higher $T_{V}^{B}$ outside the ice sheet extent are sea ice. (c) The SMAP enhanced-resolution L-band $T_{V}^{B}$ imagery is overlaid with AR-and MCoRDS-derived 2010-2017 perennial firn aquifer (blue shading; Miège et al., 2016), 2010-2014 ice slab (cyan shading; McFerrin et al., 2019), and 2012 spatially coherent melt layer (white shading; Culberg et al., 2021) detections along OIB flight lines (black lines). Overlapping perennial firn aquifer and ice slab detections are interpreted as perched firn aquifer areas. The red and orange boxes in (c) are zoom areas over south eastern Greenland (Fig. 2a), and south western Greenland (Fig. 2b), respectively. The red line is $A R$ radargram profile along perennial firn aquifer transect $A-B$ (Fig. 3a). The orange line is $A R$ radargram profile along ice slab transect C-D (Fig. 3b). 
https://doi.org/10.5194/tc-2021-116

Preprint. Discussion started: 30 April 2021

(c) Author(s) 2021. CC BY 4.0 License.

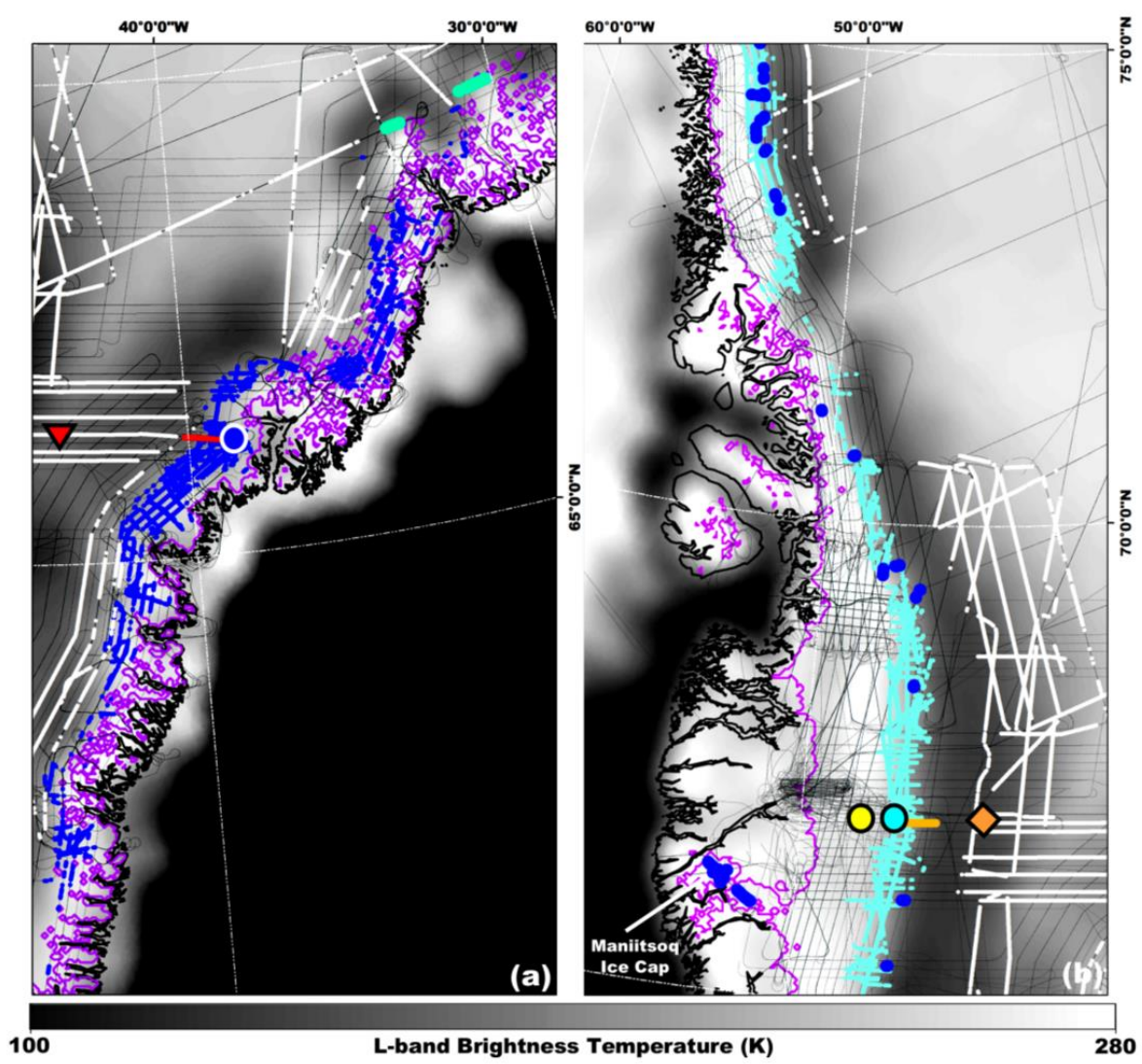

\section{Figure 2}

323 Enhanced-resolution (3.125 km) L-band $T_{V}^{B}$ imagery generated using observations collected 15 April 2016 by the microwave radiometer on the SMAP satellite during the evening orbital pass interval over (a) south eastern Greenland (Fig. 1C; zoom area in red box), and (b) south western Greenland (Fig. 1c; zoom area in orange box) (Brodzik et al., 2019). The purple line is the ice sheet or ice cap extent (Howat et al., 2014). The black peripheral line is the coast (Wessel and Smith, 1996). (c) The SMAP enhanced-resolution Lband $T_{V}^{B}$ imagery is overlaid with AR- and MCoRDS-derived 2010-2017 perennial firn aquifer (blue shading; Miège et al., 2016), 2010-2014 ice slab (cyan shading; McFerrin et al., 2019), and 2012 spatially coherent melt layer (white shading; Culberg et al., 2021) detections along OIB flight lines (black lines). Overlapping perennial firn aquifer and ice slab detections are interpreted as perched firn aquifer areas. The red line is $A R$ radargram profile along perennial firn aquifer transect $A-B$ (Figs. 1; 3a). The orange line is $A R$ radargram profile along ice slab transect $C-D$ (Figs. 1; 3b). The blue circle is a perennial firn aquifer area (Figs. 3a; 4a). The cyan circle is a perched firn aquifer area (Figs. 3b; 4b). The orange diamond is a percolation facies area (Fig. 4C). The red triangle is a high-elevation ( 2500 m.a.s.l.) percolation facies area (Fig. 4d). The yellow circle is a superimposed ice area (Fig. 4e). 
https://doi.org/10.5194/tc-2021-116

Preprint. Discussion started: 30 April 2021

(C) Author(s) 2021. CC BY 4.0 License.

Annual perennial firn aquifer and ice slab detections that may introduce significant uncertainty into the multi-year calibration technique include those following the 2010 melting season, which was exceptionally long (Tedesco et al., 2010), the anomalous 2012 melting season (Nghiem et al., 2012), and the 2015 melting season which was especially intense in western and northern Greenland (Tedesco et al., 2016). Following these extreme melting seasons, significant changes in the dielectric and geophysical properties likely occurred across large portions of the GrIS, including perennial firn aquifer recharging resulting in increases in meltwater volume and decreases in the depth to the upper surface of stored meltwater. The formation of expansive near-surface ice slabs (McFerrin et al., 2019) likely resulted in the formation of more extensive perched firn aquifers during subsequent melting seasons. The upper snow and firn layers of the dry snow facies and percolation facies were also saturated with relatively large volumetric fractions of meltwater as compared to the negligible to limited volumetric fractions of meltwater that percolates during more typical seasonal surface melting on the GrIS. Seasonal meltwater was refrozen into spatially coherent melt layers following the 2010 and 2012 melting seasons (Culberg et al., 2021) as well as following the 2015 and 2018 melting seasons (i.e., identified as part of the temporal L-band signature analysis in this study; see Section 2.4.2).

As compared to ice slabs, which are dense low-permeability solid-ice layers, spatially coherent melt layers are a network of embedded ice structures primarily consisting of discontinuous horizontally-oriented ice layers and ice lenses sparsely connected via vertical-oriented ice pipes (Culberg et al., 2021). Ice slabs are relatively thick $(\sim 1 \mathrm{~m}-16 \mathrm{~m})$ and form in the high-elevation percolation facies ( 2100 m.a.s.l.) at depths of between $\sim 1 \mathrm{~m}$ and $20 \mathrm{~m}$ beneath the ice sheet surface following intense seasonal surface melting over multiple melting seasons (McFerrin et al., 2019). Spatially coherent melt layers are relatively thin $(\sim 0.02 \mathrm{~cm}$ - $2 \mathrm{~m}$ ) and can rapidly form across the entire high-elevation dry snow facies ( 3200 m.a.s.l ; Nghiem et al., 2012) at depths of less than $\sim 1 \mathrm{~m}$ beneath the ice sheet surface following a single extreme melting season. They can further merge together into thicker solid-ice layers following multiple extreme melting seasons (Culberg et al., 2021). Similar to ice slabs, the formation of spatially coherent melt layers reduces the pore space within the upper snow and firn layers and may also facilitate lateral meltwater flow with minimum vertical percolation into the deeper firn layers, thus enhancing meltwater run-off from significantly higher elevations downslope towards the periphery on accelerated time scales. The formation of spatially coherent melt layers overlying deeper perennial firn aquifers (e.g., Fig. 3a) will limit or terminate gravity-driven meltwater drainage and seasonal recharging (Fountain and Walder, 1998), which may eventually completely refreeze stored meltwater into decimeters thick solid-ice layers overlying deeper glacial ice.

368 Spatially coherent melt layers are exceptionally bright in AR radargrams (e.g., Fig 3a). The large dielectric 369 contrast between the spatially coherent melt layer and the overlying, underlying, and interior snow and firn 370 layers results in high reflectivity at the interfaces. However, electromagnetic energy still propagates 371 downward through the high reflectivity layer into the deeper firn layers. Culberg et al., 2021) recently 372 demonstrated mapping the extent of the spatially coherent melt layer formed following the anomalous 2012 melting season (Nghiem et al., 2012) via AR (Figs. 1c; 2). 
https://doi.org/10.5194/tc-2021-116

Preprint. Discussion started: 30 April 2021

(c) Author(s) 2021. CC BY 4.0 License.
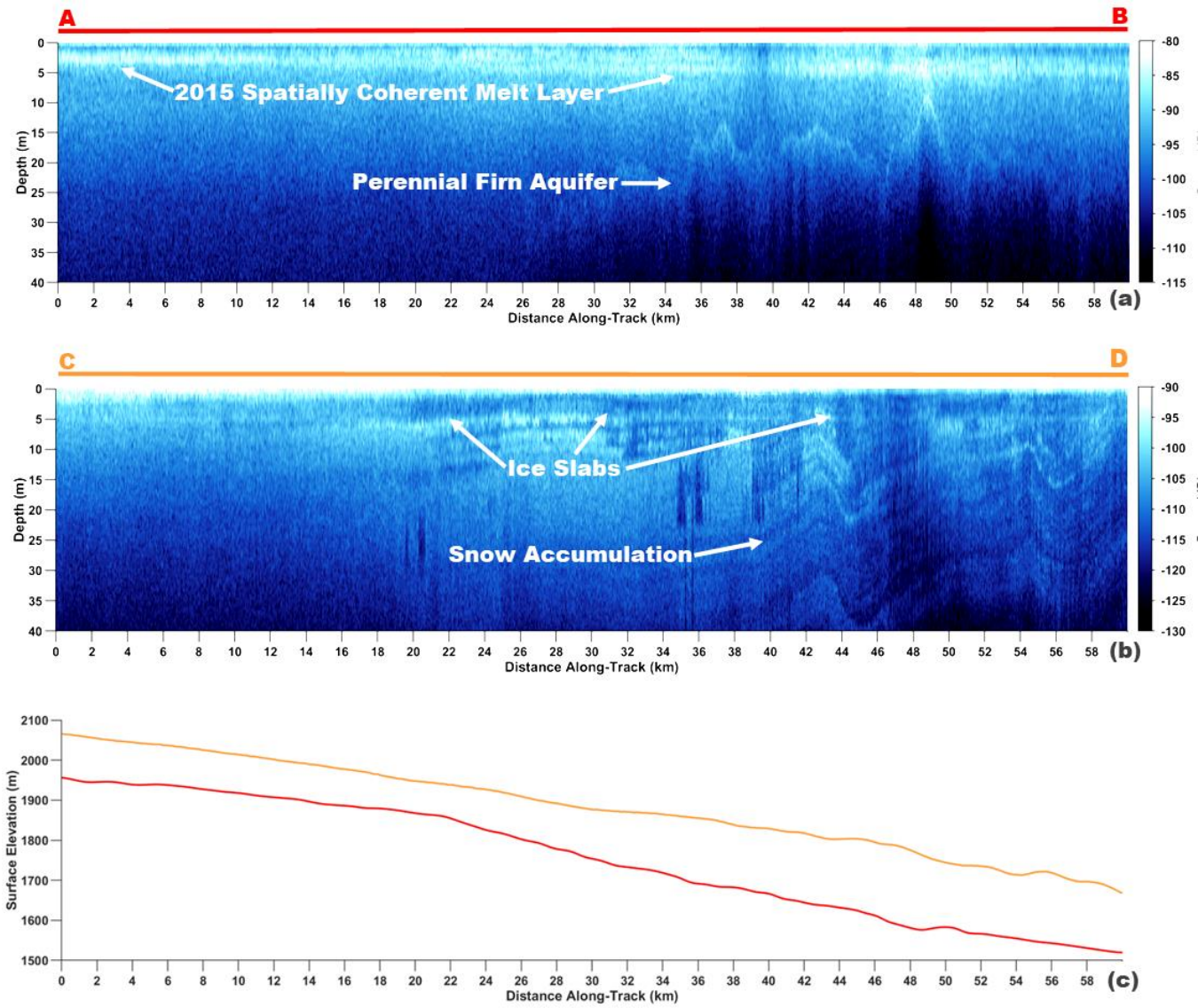

375 Figure 3

376 AR radargram profile (Rodriguez-Morales et al, 2014) (a) along perennial firn aquifer transect $A-B$ (red line,

377 Figs. 1; 2a) that was collected on 22 April 2017, and (b) ice slab transect C-D (orange line, Figs. 1; 2b) that 378 was collected on 5 May 2017. (c) The corresponding perennial firn aquifer transect $A-B$ elevation profile 379 (red line), and ice slab transect $C$ - $D$ elevation profile (orange line). The exceptionally bright upper surface380 parallel reflector in (a) is interpreted as a spatially coherent melt layer that formed following the 2015 melting 381 season. The bright lower reflector in (a) is interpreted as the upper surface of meltwater stored within a perennial firn aquifer. Thick dark surface-parallel regions of low-reflectivity in (b) are interpreted as ice slabs. Alternating sequences of bright and dark surface-parallel reflectors in (b) are interpreted as seasonal snow accumulation layers. A first maximum after maximum gradient re-tracker is used to identify the surface return in each profile. Each profile is flattened so that the depth axis is measured relative to the local elevation. Corresponding elevation profiles in (c) are calculated by subtracting the radar-measured flight clearance over the ice sheet from the aircraft's global positioning system altitude measurements that were 
https://doi.org/10.5194/tc-2021-116

Preprint. Discussion started: 30 April 2021

(C) Author(s) 2021. CC BY 4.0 License.

AR and MCoRDS (Rodriguez-Morales et al, 2014) were flown over the GrIS on a P-3 aircraft in April and May between 2010 and 2017. The AR instrument operates at a center frequency of $750 \mathrm{MHz}$ with a bandwidth of $300 \mathrm{MHz}$, resulting in a range resolution in firn of $0.53 \mathrm{~m}$ (Lewis et al., 2015). The collected data have an along-track resolution of $\sim 30 \mathrm{~m}$ with $15 \mathrm{~m}$ spacing between traces in the final processed radargrams. At a nominal flight altitude of $500 \mathrm{~m}$ above the ice sheet surface, the cross-track resolution varies between $20 \mathrm{~m}$ for a smooth surface, to $54 \mathrm{~m}$ for a rough surface with no appreciable layover. The MCoRDS instrument operated at three different frequency configurations: (1) a center frequency of 195 $\mathrm{MHz}$ with a bandwidth of $30 \mathrm{MHz}(2010-2014,2017,2018)$, (2) a center frequency of $315 \mathrm{MHz}$ with a band width of $270 \mathrm{MHz}$ (2015), and (3) a center frequency of $300 \mathrm{MHz}$ with a bandwidth of $300 \mathrm{MHz}$ (2016). The vertical range resolution in firn for each of these frequency configurations is $5.3 \mathrm{~m}, 0.59 \mathrm{~m}$, and $0.53 \mathrm{~m}$, respectively (CReSIS, 2016). The collected data have an along-track resolution of $\sim 25 \mathrm{~m}$ with $14 \mathrm{~m}$ spacing between traces in the final processed radargrams. At the same nominal flight altitude of $500 \mathrm{~m}$, the crosstrack resolution varies between $40 \mathrm{~m}$ for a smooth surface in the highest bandwidth configuration, to 175 $\mathrm{m}$ for a rough surface with no appreciable layover in the lowest bandwidth configuration.

The multi-year calibration technique uses perennial firn aquifer detections previously identified along OIB flight lines via AR (2010-2014) and MCoRDS (2015-2017) radargram profiles and the methodology described in Miège et al. (2016). Bright lower reflectors that undulate with the local topographic gradient underneath which reflectors are absent in the percolation facies are interpreted as the upper surface of meltwater stored within perennial firn aquifers (e.g., Fig. 3a). The large dielectric contrast between refrozen and water-saturated firn layers results in high reflectivity at the interface. However, the presence of meltwater increases attenuation, limiting the downward propagation of electromagnetic energy through the water-saturated firn layer. The total number of AR derived perennial firn aquifer detections is $\sim 325,000$, corresponding to a total extent of $\sim 98 \mathrm{~km}^{2}$. The analysis assumes a smooth surface, which is typical of much of the percolation facies, and a grid cell size of $15 \mathrm{~m} \times 20 \mathrm{~m}$. The total number of MCoRDSderived perennial firn aquifer detections is $\sim 142,000$, corresponding to a total extent of $\sim 80 \mathrm{~km}^{2}$. This also assumes a smooth surface, and a grid cell size of $14 \mathrm{~m} \times 40 \mathrm{~m}$. The combined total number of grid cells $(\sim 467,000)$ and total extent $\left(\sim 178 \mathrm{~km}^{2}\right)$ is significantly larger than the total number of MCoRDS-derived grid cells $(\sim 78,000)$ and total extent $\left(\sim 44 \mathrm{~km}^{2}\right)$ calculated for 2016 (Miller et al., 2020). Perennial firn aquifer detections are mapped in western, southern, and south and central eastern Greenland as well as the Maniitsoq and Flade Isblink Ice Caps (Figs. 1c; 2a). We project AR- and MCoRDS-derived perennial firn

419 aquifer detections on the NH EASE-Grid 2.0 at an rSIR grid cell spacing of $3.125 \mathrm{~km}$. Each rSIR grid cell 420 has an extent of $\sim 10 \mathrm{~km}^{2}$. The total number of rSIR grid cells with at least one perennial firn aquifer detection is $\sim 800$, corresponding to a total extent of $\sim 8000 \mathrm{~km}^{2}$. However, given the limited AR and MCoRDS grid cell coverage, less than $\sim 1 \%$ of the rSIR grid cell extent has radargram coverage. As compared to the total number of MCoRDS-derived perennial firn aquifer detections ( 780) calculated for 2016 (Miller et al., 2020),

424 the total number of rSIR grid cells with at least one detection is only increased by $\sim 20$ for the multi-year 425 

radargram profiles and the methodology described in McFerrin et al. (2019) in the multi-year calibration technique. Thick dark surface-parallel regions of low-reflectivity in the percolation facies are interpreted as ice slabs (Fig. 3b). The large dielectric contrast between ice slabs and the overlying and underlying snow and firn layers results in high reflectivity at the interfaces. However, electromagnetic energy is not scattered or absorbed within the homogeneous ice slab, it instead propagates downward through the layer and into the deeper firn layers. The total number of AR-derived ice slab detections is $\sim 505,000$, corresponding to a total extent of $\sim 283 \mathrm{~km}^{2}$. Ice slab detections are mapped in western, central and north eastern, and northern Greenland as well as the Flade Isblink Ice Cap (Figs. 1c; 2b). We project the AR-derived ice slab detections on the NH EASE-Grid 2.0 at an rSIR grid cell spacing of $3.125 \mathrm{~km}$. The total number of rSIR grid cells with at least one ice slab detection is $\sim 2000$, corresponding to a total extent of $\sim 20,000 \mathrm{~km}^{2}$. However, less than $\sim 2 \%$ of the rSIR grid cell extent has radargram coverage.

We detect perched firn aquifer areas by comparing the AR- and MCoRDS-derived perennial firn aquifer and ice slab detections projected on the NH EASE-Grid 2.0 and then identify overlapping rSIR grid cells. The total number of AR-derived perched firn aquifer detections is $\sim 75,000$, corresponding to a total extent of $\sim 23 \mathrm{~km}^{2}$. The total number of MCoRDS-derived perched firn aquifer detections is $\sim 20$, corresponding to a near-negligible extent $\left(\sim 0.006 \mathrm{~km}^{2}\right)$. Perched firn aquifer detections are mapped in western, and central eastern Greenland as well as the Flade Isblink Ice Cap (Figs. 1c; 2b).

The total number of rSIR grid cells with at least one perched firn aquifer detection is $\sim 200$, corresponding to a total extent of $\sim 2000 \mathrm{~km}^{2}$. However, similar to the other sub-facies, less than $\sim 1 \%$ of the rSIR grid cell extent has radargram coverage. The total number of AR- and MCoRDS-derived perennial firn aquifer, ice slab, and perched firn aquifer detections that we project on three separate NH EASE-Grids 2.0, the associated total number of rSIR grid cells that we use in the calibration of our adapted empirical algorithm, and the coverage of detections and rSIR grid cells over each of the three sub-facies within the broader percolation facies are summarized in Table 1.

Table 1. The total number of airborne ice penetrating radar survey detections (2010-2017), the associated total number of rSIR grid cells, and the coverage of detections and rSIR grid cells over perennial firn aquifer, ice slab, and perched firn aquifer areas.

\begin{tabular}{ccccc}
\hline & Detections & $\begin{array}{c}\text { Coverage } \\
\left(\mathbf{k m}^{2}\right)\end{array}$ & $\begin{array}{c}\text { rSIR Grid } \\
\text { Cells }\end{array}$ & $\begin{array}{c}\text { Coverage } \\
\left(\mathbf{k m}^{2}\right)\end{array}$ \\
\hline Perennial Firn Aquifers & $\sim 467,000$ & $\sim 178$ & $\sim 80$ & $\sim 8000$ \\
\hline Ice Slabs & $\sim 505,000$ & $\sim 283$ & $\sim 2000$ & $\sim 20,000$ \\
\hline Perched Firn Aquifers & $\sim 75,000$ & $\sim 23$ & $\sim 200$ & $\sim 2000$
\end{tabular}


https://doi.org/10.5194/tc-2021-116

Preprint. Discussion started: 30 April 2021

(C) Author(s) 2021. CC BY 4.0 License.

(c) (i)

\section{$457 \quad 2.4 \quad$ Empirical Algorithm}

\section{2.4.1 Greenland's Ice Facies}

459 Greenland's ice facies (i.e., dry snow facies - percolation facies - wet snow facies - ablation facies) were

460 first described in detail by Benson et al., (1960), and were shown to represent the GrIS's response to

461 climate. Evolution of the boundaries of Greenland's ice facies are often used as an indicator of climate

462 change. Early studies using field-based (Jezek et al., 1994; Zabel et al., 1995), airborne (Swift et al., 1985;

463 Bindschadler et al., 1987; Rignot et al., 1993; Jezek et al., 1993), and satellite (Fahnestock et al., 1993;

464 Long and Drinkwater, 1994; Parrington, 1998) synthetic aperture radars and radar scatterometers operating

465 at frequencies between $\mathrm{Ku}$-band $(13 \mathrm{GHz})$ and $\mathrm{P}$-band $(0.4 \mathrm{GHz})$ have demonstrated the exceptional

466 capabilities of microwave sensors for mapping Greenland's ice facies. Early airborne studies using C-band

467 microwave radiometry (Swift et al., 1985), and more recent studies using L-band microwave radiometry

468 (Jezek et al. 2018) have demonstrated similar capabilities. In this study, we extend these capabilities to

469 include satellite L-band microwave radiometry. We delineate the boundaries of the percolation facies

470 relative to the adjacent dry snow facies (i.e., where negligible seasonal surface melting occurs) and wet

471 snow facies (i.e., where snow layers are fully water-saturated during the melting season and subsequently

472 refreeze as superimposed ice overlying deeper glacial ice). And, we further identify sub-facies (i.e.,

473 perennial firn aquifer, ice slabs, and perched firn aquifers) within the broader percolation facies that are

474 currently experiencing rapid expansion (McFerrin et al., 2019; Culberg et al., 2021) as Greenland's climate

475 continues to warm (Hanna et al., 2013; Cullather et al., 2020) and seasonal surface melting increases in

476 extent, intensity, and duration (Steffen et al., 2004; Tedesco e al., 2008; Tedesco et al., 2011; Nghiem et

477 al., 2012; Tedesco et al., 2016; Tedesco and Fettweis, 2020; Tedesco and Fettweis, 2020). Higher

478 frequency microwave sensors provide shallower penetration depths, and an increased sensitivity to snow

479 grain size, layering, embedded ice structures (Long and Drinkwater, 1994; Drinkwater et al., 2001) and

480 stored meltwater (Jezek et al., 1993; Miller, 2019) within the upper snow and firn layers of the percolation

481 facies. Lower frequencies provide deeper penetration depths and a range of sensitivities to embedded ice

482 structures (Jezek et al., 1993; Jezek et al., 2018) and stored meltwater (Miller et al., 2020) in the deeper

483 firn layers.

484

$485 \quad$ 2.4.2 Temporal L-band signatures over the percolation facies

486 Microwave brightness temperature $\left(T^{B}\right)$ expresses the satellite-observed magnitude of thermal emission

487 and is influenced by the observation geometry as well as the dielectric and geophysical properties of the

488 ice sheet (Ulaby et al., 2014). The most significant geophysical property influencing $T^{B}$ is the volumetric

489 fraction of meltwater within the snow and firn pore space (Mätzler and Hüppi, 1989). During the melting

490 season, the upper snow and firn layers of the percolation facies are saturated with large volumetric fractions

491 of meltwater that percolates vertically into the deeper firn layers (Benson, 1960; Humphrey et al., 2012).

492 Increases in the volumetric fraction of meltwater results in rapid relative increases in the imaginary part of 
https://doi.org/10.5194/tc-2021-116

Preprint. Discussion started: 30 April 2021

(C) Author(s) 2021. CC BY 4.0 License.

493 the complex dielectric constant (Tiuiri et al., 1984), with corresponding increases in $T^{B}$. This increase is 494 attributed to a decrease in volume scattering, and penetration depth. The L-band penetration depth can 495 rapidly decrease from tens to hundreds of meters, to less than a meter, dependent on the local snow 496 and firn conditions, and englacial firn hydrological features. Surface and subsurface water-saturated snow 497 and firn layers and embedded ice structures subsequently refreeze. During the freezing season, decreases 498 in the volumetric fraction of meltwater results in rapid relative decreases in the imaginary part of the complex 499 dielectric constant, with corresponding decreases in $T^{B}$. This increase is attributed to an increase in volume 500 scattering, and penetration depth. The L-band penetration depth increases back to tens to hundreds of 501 meters on variable time scales.

$502 \quad$ We analyze melting and freezing seasons in temporal L-band signatures exhibited in $T_{V}^{B}$ time series 503 (1 April 2015 - 31 March 2019) over and near AR- and MCoRDS-derived perennial firn aquifer, ice slab, 504 and perched firn aquifer detections projected on NH EASE-Grids 2.0 (Fig. 4). We project ice surface 505 temperature data calculated using thermal infrared brightness temperature collected by the Moderate 506 Resolution Imaging Spectroradiometer (MODIS) on the Terra and Aqua satellites (i.e., Hall et al., 2012) on 507 coincident NH EASE-Grids 2.0 at a $3.125 \mathrm{~km}$ rSIR grid cell spacing. We then derive melt onset and surface 508 freeze-up dates (2015-2019) for each rSIR grid cell using the methodology described in Miller et al., (2020). 509 We set a threshold of ice surface temperature $>-1^{\circ} \mathrm{C}$ for meltwater detection (Nghiem et al., 2012), 510 consistent with the $\pm 1^{\circ} \mathrm{C}$ accuracy of the ice surface temperature data. For temperatures that are close to $5110^{\circ} \mathrm{C}$, ice surface temperatures are closely compatible with contemporaneous NOAA near-surface air 512 temperature data (Shuman et al., 2014). Melt onset and surface freeze-up dates are overlaid on $T_{V}^{B}$ time 513 series to partition the melting and freezing seasons. Melt onset dates occur between $\sim$ April and July, and 514 surface freeze-up dates occur between July and September. The melting season increases in duration 515 moving downslope from the dry snow facies, and ranges from a single day in the highest elevations ( $>2500$ $516 \mathrm{~m}$ ) of the percolation facies, to $\sim 150$ days in the ablation facies. Similarly, the associated freezing season 517 decreases in duration moving downslope and ranges from between 215 days and 365 days.

518 Over perennial firn aquifer areas (e.g., Figs. 1c; 2a; 4a), $T_{V}^{B}$ is radiometrically warm during the 519 melting season. Vertically percolating meltwater and gravity-driven meltwater drainage seasonally 520 recharges perennial aquifers at depth (Fountain and Walder et al., 1998). Maximum values range from 521 between $\sim 200 \mathrm{~K}$ and $275 \mathrm{~K}$ during seasonal surface melting. Temporal L-band signatures exhibit increases 522 on time scales of $\sim$ days to weeks following the melt onset date, and melting seasons range from between $523 \sim 75$ and 100 days. $T_{V}^{B}$ remains radiometrically warm during the freezing season as a result of latent heat 524 continuously released by the slow refreezing of the deeper firn layers that are saturated with large 525 volumetric fractions of meltwater (Miller et al, 2020). Minimum values range from between $\sim 180 \mathrm{~K}$ and 250 $526 \mathrm{~K}$ following the surface freeze-up date. L-band emissions from the radiometrically warm upper snow and 527 firn layers decrease during the freezing season as embedded ice structures slowly refreeze at increased 528 depths below the ice sheet surface (Miller et al., 2020). Temporal L-band signatures exhibit exponential 529 decreases on time scales of $\sim$ months that approach and sometimes achieve relatively stable $T_{V}^{B}$ values, 
https://doi.org/10.5194/tc-2021-116

Preprint. Discussion started: 30 April 2021

(c) Author(s) 2021. CC BY 4.0 License.
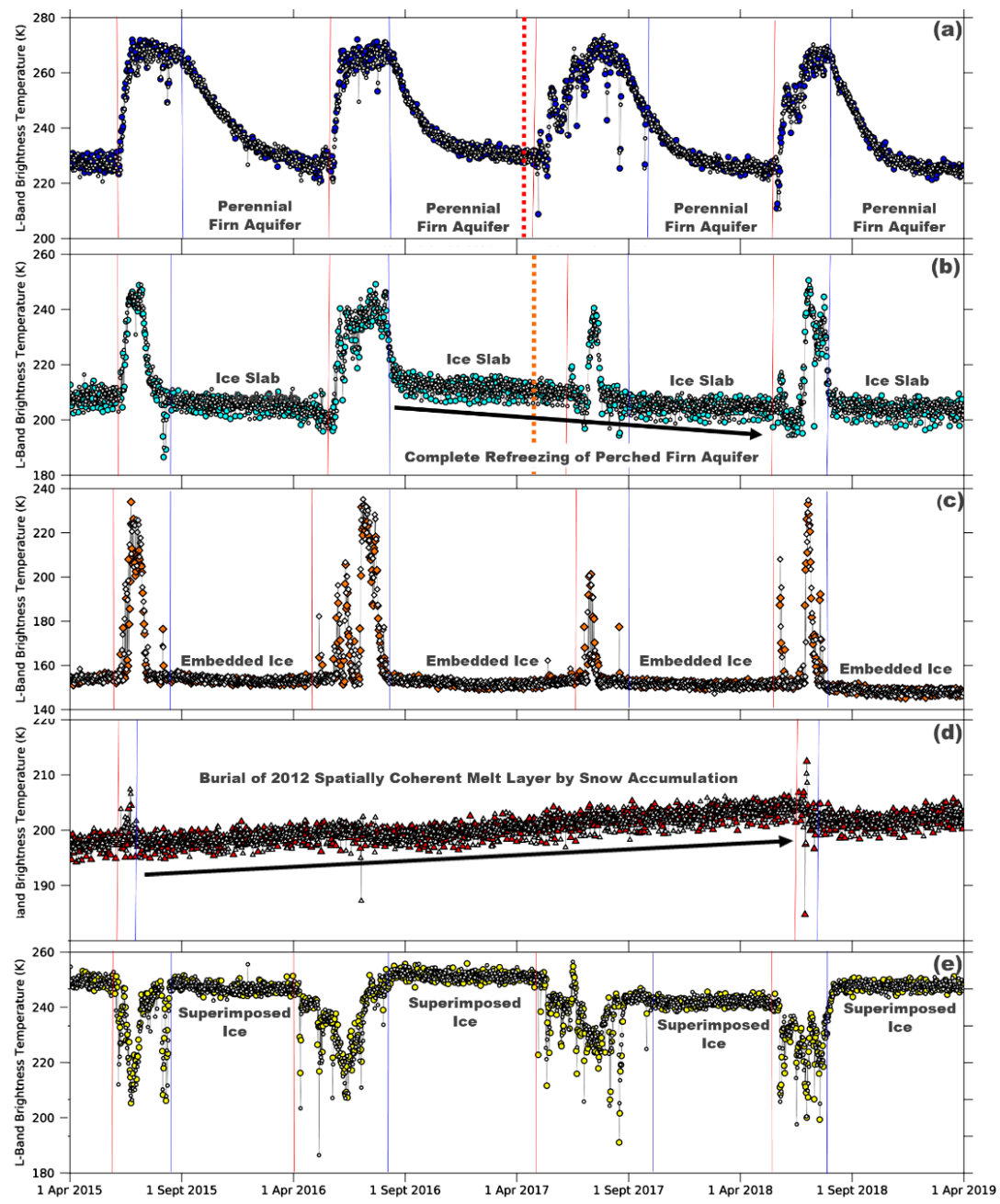

\section{$531 \quad$ Figure 4}

532 Temporal L-band signatures that alternate morning (white symbols) and evening (colored symbols) orbital

533 pass interval enhanced-resolution $T_{V}^{B}$ generated using observations collected over the GrlS by the 534 microwave radiometer on the SMAP satellite (Brodzik et al., 2019) over (a) perennial firn aquifer area (blue 535 circles; Figs. 2a; 3a), (b) perched firn aquifer area (cyan circles; Figs. 2b; 3b), (c) percolation facies area 536 (orange diamonds; Fig 2b), (d) high-elevation ( 2500 m.a.s.l.) spatially coherent melt layer area (red 537 triangles; Fig. 2a), and (e) superimposed ice area (yellow circles; Fig. 2b). Melt onset (red lines) and surface 538 freeze-up (blue lines) dates are derived from thermal infrared $T^{B}$ collected by MODIS on the Terra and 539 Aqua satellites (Hall et al, 2012). AR radargram profile along perennial firn aquifer transect $A-B$ (red dashed 540 line; Figs. 1; 2a; 3a) that was collected on 22 April 2017, and ice slab transect C-D (orange dashed line; 541 Figs. 1; 2b; 3b) that was collected on 5 May 2017. 
https://doi.org/10.5194/tc-2021-116

Preprint. Discussion started: 30 April 2021

(C) Author(s) 2021. CC BY 4.0 License.

542 and freezing seasons range from between $\sim 265-290$ days. $T_{V}^{B}$ often decreases by more than $\sim 50 \mathrm{~K}$ during 543 the freezing season (e.g., Fig. 4a), representing the descent of the upper surface of stored meltwater by 544 tens of meters (Miège et al., 2016).

$545 \quad$ Over ice slab and perched firn aquifer areas (e.g., Figs. 1c; $2 b ; 5 b), T_{V}^{B}$ is typically radiometrically 546 colder than over perennial firn aquifer areas during the melting season. The presence of dense low547 permeability solid-ice layers (e.g., Fig. 3b) reduces the snow and firn pore space available to store seasonal 548 meltwater at depth. Meltwater may alternatively run-off downslope towards the wet snow facies. Maximum 549 values range from between $\sim 170 \mathrm{~K}$ and $260 \mathrm{~K}$ during seasonal surface melting. Temporal L-band signatures 550 exhibit increases on time scales of $\sim$ days to weeks following the melt onset date, and melting seasons 551 range from between $\sim 60$ and 90 days. $T_{V}^{B}$ is also typically radiometrically colder than over perennial firn 552 aquifer areas during the freezing season as a result of the absence of meltwater stored at depth (i.e. ice 553 slab areas), or the presence of limited volumetric fractions of meltwater stored at depth in shallow water554 saturated firn layers (i.e. perched firn aquifer areas). Minimum values range from between $\sim 130 \mathrm{~K}$ and 240

$555 \mathrm{~K}$ following the surface freeze-up date. Temporal L-band signatures exhibit exponential decreases on time 556 scales of $\sim$ weeks to months that often achieve relatively stable $T_{V}^{B}$ values, and freezing seasons range from 557 between $\sim 275-305$ days. Exponentially decreasing temporal L-band signatures sometimes transition to 558 linearly decreasing on time scales of years following the surface freeze-up date (e.g., between $559 \sim$ September 2016 and May 2018 in Fig. 4b). We infer this indicates the formation and subsequent refreezing 560 of a shallow perched firn aquifer on top of a buried ice slab or other semi-impermeable layer. As compared 561 to the large $T_{V}^{B}$ decreases in percolation facies areas, $T_{V}^{B}$ decreases over perched firn aquifer areas are as 562 small as a few $\mathrm{K}$ annually, which represents the descent of the upper surface of stored meltwater by $563 \sim$ meters rather than by $\sim$ tens of meters.

564 Over other percolation facies areas, where seasonal meltwater is fully refrozen and stored 565 exclusively as embedded ice (e.g., Fig. 4c), $T_{V}^{B}$ is typically radiometrically colder than over perennial firn 566 aquifer, ice slab, and perched firn aquifer areas during the melting season. Maximum values range from 567 between $\sim 150 \mathrm{~K}$ and $200 \mathrm{~K}$ during seasonal surface melting. Temporal L-band signatures exhibit increases 568 on time scales of $\sim$ days to weeks following the melt onset date, and melting seasons range from between

$569 \sim 1$ and 60 days. $T_{V}^{B}$ is also typically radiometrically cold during the freezing season. Minimum values range 570 from between $\sim 130 \mathrm{~K}$ and $180 \mathrm{~K}$ following the surface freeze-up date. Temporal L-band signatures exhibit 571 exponential decreases on time scales of $\sim$ days to weeks and achieve relatively stable $T_{V}^{B}$ values, and 572 freezing seasons range from between $\sim 305-364$ days. However, over the highest elevations (> 2500 573 m.a.s.l.) of the percolation facies approaching the dry snow line, where seasonal surface melting and the 574 formation of embedded ice structures is limited, $T_{V}^{B}$ remains radiometrically warm during the freezing 575 season. Minimum values range from between $\sim 180 \mathrm{~K}$ and $220 \mathrm{~K}$ following the surface freeze-up date. We 576 infer $T_{V}^{B}$ decreases, sometimes step-responses exceeding $\sim 10 \mathrm{~K}$, that follow the surface freeze-up date 577 (e.g., between April 2018 and September 2018 in Fig. 4c) are a result of an increase in volume scattering 578 from newly formed embedded ice structures within a spatially coherent melt layer. We also infer that 
https://doi.org/10.5194/tc-2021-116

Preprint. Discussion started: 30 April 2021

(c) Author(s) 2021. CC BY 4.0 License.

(c) (i)

579 temporal L-band signatures that increase several K on time scales of $\sim$ years (e.g., between $\sim$ April 2015

580 and April 2018 in Fig. 4c) indicate the burial of spatially coherent melt layers formed following the 2010 ,

5812012,2015 , and 2018 melting seasons by snow accumulation.

$582 \quad$ Exponentially decreasing temporal L-band signatures transition smoothly between perennial firn

583 aquifer, ice slab, perched firn aquifer, and other percolation facies areas - there are no distinct temporal L-

584 band signatures that delineate boundaries between these sub-facies. Boundary transitions between other

585 facies, however, are delineated both above and below the percolation facies. Over the dry snow facies

586 (e.g., Fig. 4d), $T_{V}^{B}$ is radiometrically warm during the melting and freezing seasons. Values range from

587 between $\sim 200 \mathrm{~K}$ and $240 \mathrm{~K}$. While $T_{V}^{B}$ is known to be relatively stable in the dry snow facies, temporal L-

588 band signatures that increase on time scales of $\sim$ years are observed throughout this region at elevations

589 as high as Summit Station ( 3200 m.a.s.I), similar to those observed in the highest elevations (> 2500

590 m.a.s.l.) of the percolation facies. We infer increasing temporal L-band signatures indicate the burial of the

591 spatially coherent melt layer formed following the anomalous 2012 melting season (Nghiem et al., 2012) by

592 snow accumulation (Culberg et al., 2021). Over the wet snow facies (e.g., Fig. 4e), where seasonal

593 meltwater is fully refrozen and stored as superimposed ice, $T_{V}^{B}$ is radiometrically warm during the melting

594 season. Maximum values range from between $\sim 230 \mathrm{~K}$ and $250 \mathrm{~K}$ during seasonal surface melting. As

595 compared to the percolation facies, where temporal L-band signatures exhibit rapid increases following

596 melt onset, temporal L-band signatures reverse and exhibit decreases on time scales of $\sim$ days to weeks,

597 and melting seasons that range between $\sim 90-120$ days. We infer these reversals are the result of high

598 reflectivity and attenuation at the fully water-saturated snow layer and/or at the wet, rough superimposed

599 ice-air interface. Meltwater runs-off superimposed ice downslope towards the ablation facies in the wet

600 snow facies. $T_{V}^{B}$ remains radiometrically warm during the freezing season. Minimum values range from

601 between $\sim 230 \mathrm{~K}$ and $250 \mathrm{~K}$ following seasonal surface melting. Temporal L-band signatures exhibit

602 increases on time scales of $\sim$ days that achieve relatively stable $T_{V}^{B}$ values, and freezing seasons range

603 from between $\sim 245$ and 275 days.

604 The MODIS-derived total number of days in the melting and freezing seasons estimated from melt

605 onset and surface freeze-up dates, the SMAP-derived maximum and minimum vertically-polarized L-band

606 brightness temperature, and the time scales of exponential decrease following the surface freeze-up date

607 estimated for each $T_{V}^{B}$ time series for rSIR grid cells over perennial firn aquifer, ice slab, perched firn aquifer,

608 and other percolation facies areas as well as for the dry snow facies, and the wet snow facies are

609 summarized in Table 2.

610

611

612

613

614

615 
https://doi.org/10.5194/tc-2021-116

Preprint. Discussion started: 30 April 2021

(c) Author(s) 2021. CC BY 4.0 License.

616 Table 2. The MODIS-derived total number of days in the melting and freezing seasons (2015-2019), the 617 SMAP-derived maximum vertically-polarized L-band brightness temperature $\left(T_{V, \text { max }}^{B}\right)$, the minimum

618 vertically-polarized L-band brightness temperature $\left(T_{V, \min }^{B}\right)$, and the time scale scales of exponential 619 decrease following the surface freeze-up date (1 April 2015 - 31 March 2019) for perennial firn aquifer, ice 620 slab, perched firn aquifer, and other percolation facies areas as well as for the dry snow facies and the wet 621 snow facies.

\begin{tabular}{cccccc}
\hline & $\begin{array}{c}\text { Melting } \\
\text { Season } \\
\text { (days) }\end{array}$ & $\begin{array}{c}\text { Freezing } \\
\text { Season } \\
\text { (days) }\end{array}$ & $\begin{array}{c}\mathbf{T}_{\mathbf{V}, \mathbf{m a x}}^{\mathbf{B}} \\
\mathbf{( K )}\end{array}$ & $\begin{array}{c}\mathbf{T}_{\mathbf{V}, \mathbf{m i n}}^{\mathbf{B}} \\
\mathbf{( K )}\end{array}$ & $\begin{array}{c}\text { Exponential } \\
\text { Decrease } \\
\text { (time scale) }\end{array}$ \\
\hline Perennial Firn Aquifers & $\sim 75-100$ & $\sim 265-290$ & $\sim 200-275$ & $\sim 180-250$ & $\begin{array}{c}\text { weeks }- \\
\text { months }\end{array}$ \\
\hline $\begin{array}{c}\text { Ice Slabs / } \\
\text { Perched Firn Aquifers }\end{array}$ & $\sim 60-90$ & $\sim 275-305$ & $\sim 170-260$ & $\sim 130-240$ & $\sim$ days - \\
\hline Percolation Facies & $\sim 1-60$ & $\sim 305-364$ & $\sim 150-200$ & $\sim 130-220$ & $\sim$ days \\
\hline Dry Snow Facies & - & 365 & $\sim 200-240$ & $\sim 200-240$ & - \\
\hline Wet Snow Facies & $\sim 90-120$ & $\sim 245-275$ & $\sim 230-250$ & $\sim 230-250$ & - \\
\hline
\end{tabular}

622

623

624

625

626

627

628

629

630

631

632

633

634

635

636

637

638

639

640

\subsubsection{L-band geophysical-brightness temperature model}

Based on our analysis of $T_{V, \text { max }}^{B}$ and $T_{V, \text { min }}^{B}$ values in temporal L-band signatures over the percolation facies, we derive a 'firn saturation' parameter using the simple two-layer L-band geophysical-brightness temperature model described in Ashcraft and Long (2006). The firn saturation parameter is similar to the 'melt intensity' parameter derived in Hicks and Long (2011) that uses enhanced resolution verticallypolarized Ku-band radar backscatter imagery (2003) collected by the SeaWinds radar scatterometer that was flown in tandem on NASA's Quick SCATterometer (QuikSCAT) satellite (Tsai et al., 2000) and JAXA's Advanced Earth Observing Satellite 2 (ADEOS-II) (Freilich et al., 1994). We use the firn saturation parameter to estimate the maximum seasonal volumetric fraction of meltwater within the saturated upper snow and firn layers of the percolation facies using $T_{V, \max }^{B}$ and $T_{V, \min }^{B}$ values extracted from $T_{V}^{B}$ time series (1 April 2015 - 31 March 2019). We calculate the firn saturation parameter for each rSIR grid cell within the ice sheet-masked extent of the GrIS as part of our adapted empirical algorithm (see Section 2.4.5).

We first describe the geophysical model as follows. We assume a base layer underlying a watersaturated firn layer with a given depth and volumetric fraction of meltwater. Each of the layers is homogenous. We next describe $T_{V}^{B}$ from the geophysical model (Eq. 1). The ice sheet is discretely layered (i.e., two-layers; the base layer, and the water-saturated firn layer) to calculate $T_{V}^{B}$ at an oblique incidence angle. Emissions from the base layer are a function of both the macroscopic roughness and the dielectric properties of the layer. They occur in conjunction with volume scattering at depth, and are locally dependent 
https://doi.org/10.5194/tc-2021-116

Preprint. Discussion started: 30 April 2021

(c) Author(s) 2021. CC BY 4.0 License.

(c) (i)

641 on englacial firn hydrological features, including embedded ice structures, spatially coherent melt layers,

642 ice slabs, and perennial and perched firn aquifers. Reflectivity at depth (i.e., at the base layer-water-

643 saturated firn layer interface), and at the ice sheet surface (i.e., at the water-saturated firn layer-air interface)

644 is neglected. The contribution from each layer is individually calculated.

645 The two-layer L-band geophysical-brightness temperature model is represented analytically by

646

$647 T_{V, \max }^{B}=T\left(1-e^{-\kappa_{e} d \sec \theta}\right)+T_{V, \min }^{B} e^{-\kappa_{e} d \sec \theta}$,

648

649

where $T_{V, \max }^{B}$ is the maximum vertically-polarized L-band brightness temperature at the ice sheet

650

surface, $T_{V, \min }^{B}$ is the minimum vertically-polarized L-band brightness temperature emitted from the base

651 layer, $T$ is the physical temperature of the water-saturated firn layer, $\theta$ is the transmission angle, $\kappa_{e}$ is the

652 extinction coefficient, and $d$ is depth.

653

We invert Eq. 1 and solve for the firn saturation parameter $(\xi)$

654

$655 \xi=\ln \left(\frac{T_{V, \max }^{B}-T}{T_{V, \text { min }}^{B}-T}\right) \cos \theta$,

656

657

where $\xi=\kappa_{e} d$. The maximum vertically-polarized L-band brightness temperature asymptotically approaches

658 the physical temperature of the water-saturated firn layer as the extinction coefficient and the depth of the

659 water-saturated firn layer increases. The extinction coefficient is defined as the sum of the Raleigh

660 scattering coefficient $\left(\kappa_{s}\right)$ and the absorption coefficient $\left(\kappa_{a}\right)$. For water-saturated firn, absorption dominates

661 over scattering, and increases in the extinction coefficient are controlled by the volumetric fraction of meltwater $\left(m_{v}\right)$. We assume that thicker water-saturated firn layers with larger volumetric fractions of

663 meltwater generate higher firn saturation parameter values. However, the thickness of the water-saturated

664 firn layer is limited by the L-band penetration depth. Theoretical L-band penetration depths calculated for a 665 water-saturated firn layer range from between $\sim 10 \mathrm{~m}$ for small volumetric fractions of meltwater $\left(m_{v}<1 \%\right)$, 666 and $\sim 1 \mathrm{~cm}$ for large volumetric fractions of meltwater $\left(m_{v}=20 \%\right.$ ) (Fig. 5). Large volumetric fractions of 667 meltwater results in high reflectivity and attenuation at the interface between water-saturated firn layers and 668 the overlying refrozen firn layers, and between glacial ice or a semi-impermeable layer and the overlying 669 water-saturated firn layers, and a radiometrically cold firn layer (e.g., Fig 5e).

670 
https://doi.org/10.5194/tc-2021-116

Preprint. Discussion started: 30 April 2021

(c) Author(s) 2021. CC BY 4.0 License.

\section{(c) (1)}
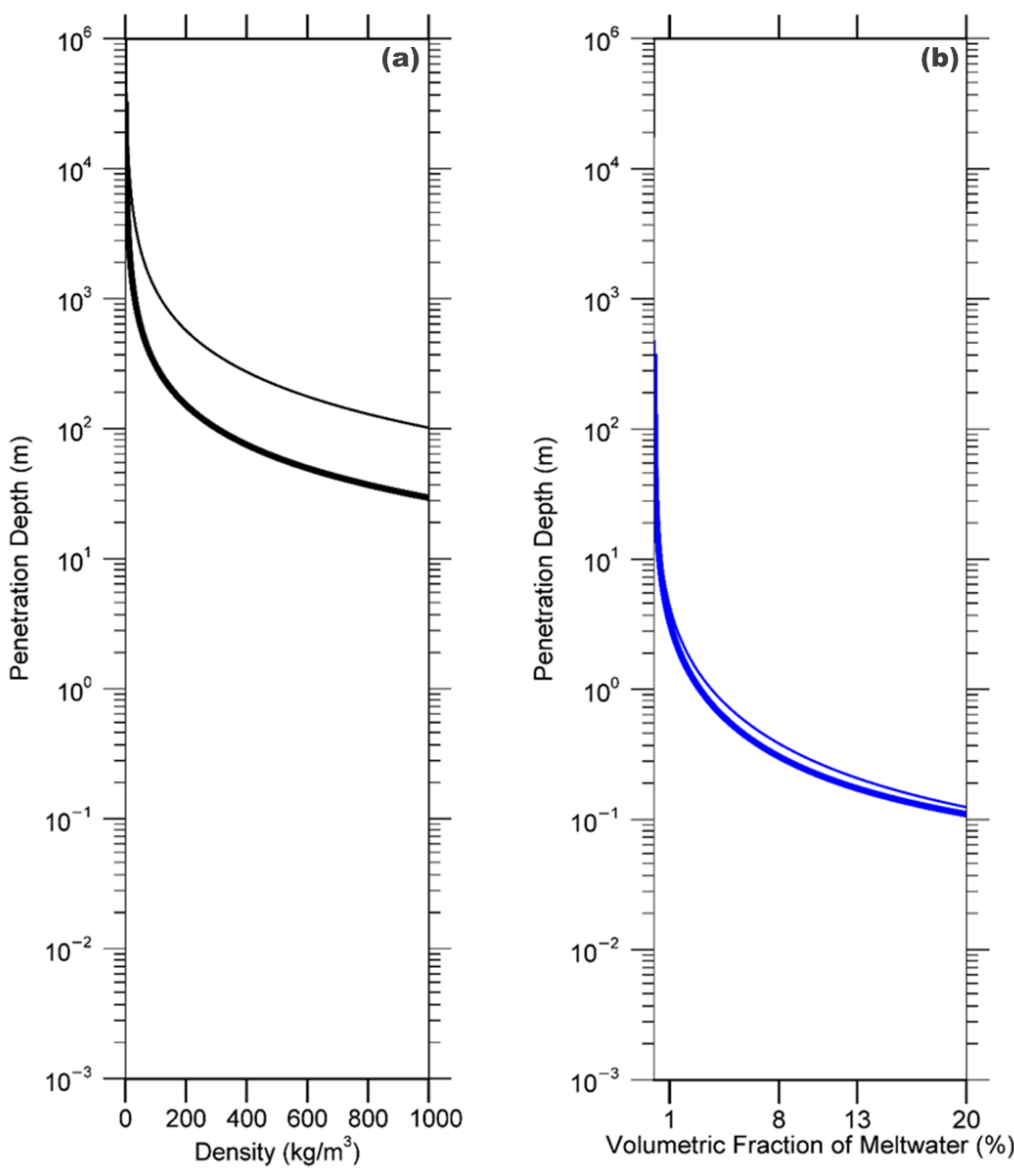

Figure 5

673 Theoretical L-band penetration depths for (a) refrozen, and (b) water-saturated firn. Penetration depths

$674\left(\frac{1}{\kappa_{s}+\kappa_{a}}\right)$ are calculated as a function of the Raleigh scattering coefficient $\left(\kappa_{s} ;\right.$ Eq. 8) and the absorption 675 coefficient ( $\kappa_{a} ;$ Eq. 10), which are functions of the dielectric and geophysical properties of the GrIS. The 676 complex dielectric constant is calculated using the empirically derived models described in Tiuri et al.,

677 (1984). Refrozen firn penetration depths are calculated as a function of firn density $\left(\rho_{\text {firn }}\right)$, and the curves 678 are plotted for snow grain radii $(r$ ) set to $r=0.5 \mathrm{~mm}$ (upper curve), and $r=4 \mathrm{~mm}$ (lower curve). Water679 saturated firn penetration depths are calculated as a function of the volumetric fraction of meltwater $\left(m_{v}\right)$, 680 and the curves are plotted for firn density set to $\rho_{\text {firn }}=400 \mathrm{~kg} / \mathrm{m}^{3}$ (upper curve), and $\rho_{\text {firn }}=917 \mathrm{~kg} / \mathrm{m}^{3}$ (lower 681 curve). Given the complexity of modeling embedded ice structures, they are excluded from the penetration 682 depth calculation. Increases in the volumetric fraction of embedded ice in the firn will result in an increase 683 in volume scattering, which will decrease and compress the distance between the penetration depth curves 684 for both refrozen and water-saturated firn. 
https://doi.org/10.5194/tc-2021-116

Preprint. Discussion started: 30 April 2021

(c) Author(s) 2021. CC BY 4.0 License.

(c) (1)

\subsubsection{Continuous logistic model}

686

687

688

689

690

691

692

693

694

695

696

697

698

699

700

701

702

703

704

705

706

707

708

709

710

$711 T_{V, N}^{B}(t)=\frac{T_{V}^{B}(t)-T_{V, \min }^{B}}{T_{V, \text { max }}^{B}-T_{V, \text { min }}^{B}}$,

712

713

714

715

716

$$
\frac{d x}{d t}=\zeta x(1-x)
$$

that has the solution

$$
x(t)=\frac{1}{1+\left(\frac{1}{x_{0}}-1\right) e^{-\zeta t}},
$$
sigmoidal curves.
We adapt our previously developed empirical algorithm to map the extent of Greenland's perennial firn aquifers (Miller et al., 2020) to also map the extent of ice slab and perched firn aquifer areas. The empirical algorithm is derived from the continuous logistic model, which is based on a differential equation that models the decrease in physical systems as a function of time using a set of sigmoidal curves. These curves begin at a maximum value with an initial interval of decrease that is approximately exponential. Then, as the function approaches its minimum value, the decrease slows to approximately linear. Finally, as the function asymptotically reaches its minimum value, the decrease exponentially tails off and achieves stable values. We use the continuous logistic model to parametrize the refreezing rate within the saturated upper snow and firn layers of the percolation facies using $T_{V}^{B}$ time series (1 April 2015 - 31 March 2019) that are partitioned using $T_{V, \text { max }}^{B}$ and $T_{V, \text { min }}^{B}$ values. We calculate the refreezing rate for each rSIR grid cell within the percolation facies extent as part of our adapted empirical algorithm (see Section 2.4.5).

The continuous logistic model is described by a differential equation known as the logistic equation

where $x_{o}$ is the function's initial value, $\zeta$ is the function's exponential rate of decrease, and $t$ is time. The function $x(t)$ is also known as the sigmoid function. We use the sigmoid function to model the exponentially decreasing temporal L-band signatures observed over the percolation facies as a set of decreasing

We first normalize $T_{V}^{B}$ time series for each rSIR grid cell

where $T_{V, \min }^{B}$ is the minimum vertically-polarized L-band brightness temperature, and $T_{V, \max }^{B}$ is the maximum vertically-polarized L-band brightness temperature. We then apply the sigmoid fit

$$
T_{V, N}^{B}\left(t \in\left[t_{\max }, t_{\min }\right]\right)=\frac{1}{1+\left(\frac{1}{T_{V, N}^{B}\left(t_{\max }\right)}-1\right) e^{-\zeta t}}
$$


https://doi.org/10.5194/tc-2021-116

Preprint. Discussion started: 30 April 2021

(c) Author(s) 2021. CC BY 4.0 License.

(c) (i)

$718 T_{V, N}^{B}\left(t \in\left[t_{\max }, t_{\min }\right]\right)$ is the normalized vertically-polarized L-band brightness temperature on the time

719 interval $t \in\left[t_{\max }, t_{\min }\right]$, where $t_{\max }$ is the time the function achieves a maximum value, and $t_{\min }$ is the

720 time the function achieves a minimum value. The initial normalized vertically-polarized L-band brightness

721 temperature $\left(T_{V, N}^{B}\left(t_{\max }\right)\right)$ is the function's maximum value. The final normalized vertically-polarized L-band brightness temperature $\left(T_{V, N}^{B}\left(t_{\min }\right)\right)$ is the function's minimum value. The function's exponential rate of decrease represents the refreezing rate parameter $(\zeta)$. An example set of simulated sigmoidal curves is shown in Fig. 6.

\subsubsection{SMAP-derived perennial firn aquifer, ice slab, and perched firn aquifer maps}

727

728

729

730

731

732

733

734

735

736

737

738

739

740

741

742

743

744

745

746

747

748

749

750

where $\rho_{\text {firn }}$ is firn density, which we set to $\rho_{\text {firn }}=400 \mathrm{~kg} / \mathrm{m}^{3}$, and $\rho_{\text {ice }}$ is ice density, which we set to $\rho_{\text {ice }}=917$ $\mathrm{kg} / \mathrm{m}^{3}$. Our grain radius and firn density estimates are consistent with measurements within the upper snow and firn layers of the percolation facies of south eastern Greenland at the Helheim Glacier field site (Fig.

Our adapted empirical algorithm uses ice sheet-masked SMAP enhanced-resolution $T_{V}^{B}$ imagery over the GrIS that alternates morning and evening orbital pass observations annually, beginning and ending just prior to melt onset. Our algorithm is implemented in two steps: (1) mapping the extent of the percolation facies using the firn saturation parameter derived from the L-band geophysical-brightness temperature model (see Section 2.4.3), and (2) mapping the extent of perennial firn aquifer, ice slab, and perched firn aquifer areas over the percolation facies using the continuous logistic model (see Section 2.4.4) we calibrate using airborne ice-penetrating radar detections projected on three separate NH EASE-Grids 2.0 (see Section 2.2).

Using Eq. 2, we first set a threshold for the firn saturation parameter $\left(\xi_{T}\right)$ defined by the relationship

$\xi_{T}=\left(\kappa_{s}+\kappa_{a}\right) d \leq \xi$.

We calculate the Raleigh scattering coefficient $\left(\kappa_{s}\right)$ in Eq. 7 using

$\kappa_{s}=N_{d} \frac{8}{3} k_{o}^{4} r^{6}\left|\frac{\varepsilon_{r}-1}{\varepsilon_{r}+2}\right|^{2}$

where $N_{d}$ is the particle density, $k_{o}$ is the wave number of the background medium of air, $r$ is the snow grain radius set to $r=2 \mathrm{~mm}$, and $\varepsilon_{r}$ is the complex dielectric constant. The particle density is defined by

$N_{d}=\frac{\rho_{\text {firn }}}{\rho_{\text {ice }}} \frac{1}{3} \pi r^{3}$, 
https://doi.org/10.5194/tc-2021-116

Preprint. Discussion started: 30 April 2021

(c) Author(s) 2021. CC BY 4.0 License.

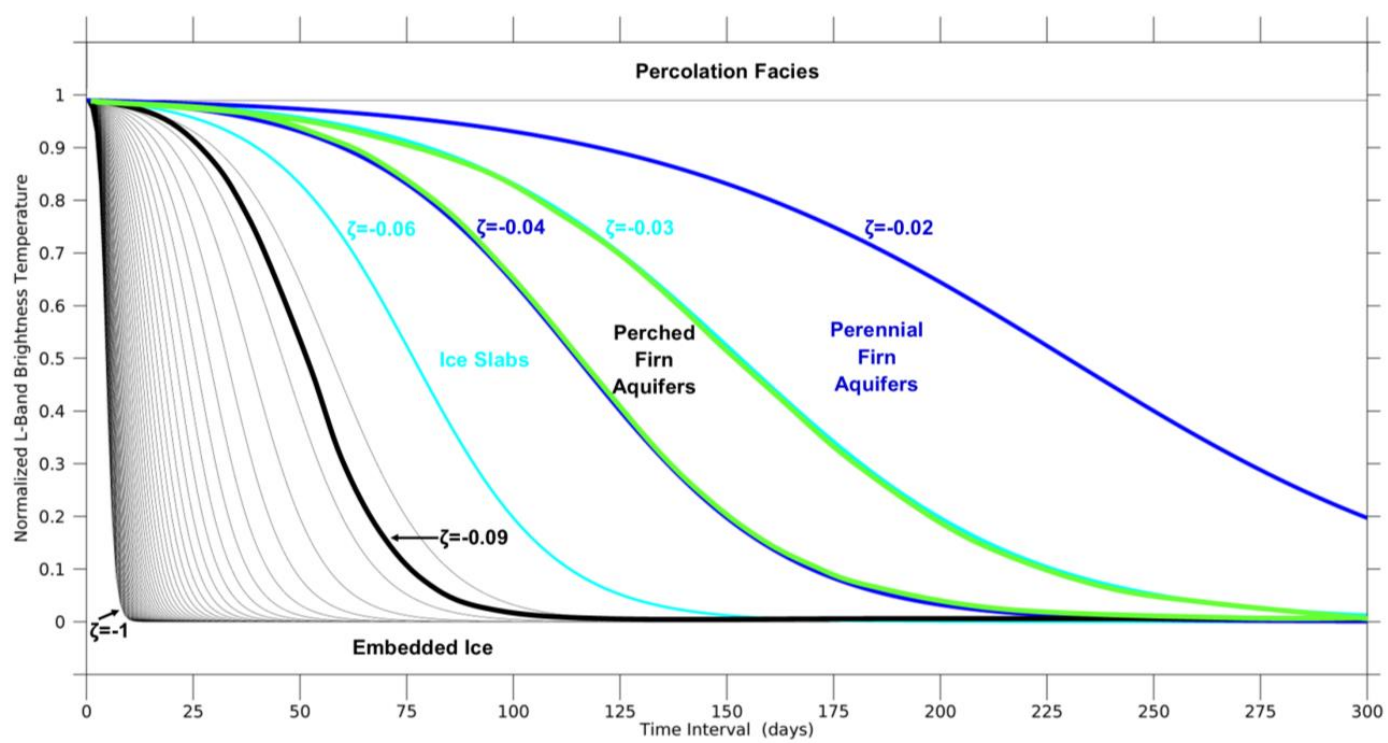

\section{Figure 6}

754 Example set of simulated sigmoidal curves that represent our model of the exponentially decreasing 755 temporal L-band signatures predicted over the percolation facies. The initial normalized vertically-polarized $756 L$-band brightness temperature was fixed at a value of $T_{V, N}^{B}\left(t_{\max }\right)=0.99$, and the time interval was set to a 757 value of $t \in\left[t_{\max }, t_{\min }\right]=300$ observations. The refreezing rate parameter was set to values between $\zeta=$ $758[-1,0]$ incremented by steps of 0.02. The blue lines correspond to the interval $\zeta \in[-0.04,-0.02]$ and produce curves similar to those observed over perennial firn aquifer areas. The cyan lines correspond to the interval $\zeta \in[-0.06,-0.03]$ and produce curves similar to those observed over ice slab areas. The green lines correspond to the interval $\zeta \in[-0.04,-0.03]$ and produce curves similar to those observed over perched firn aquifer areas. The black line is the observed lower bound $(\zeta=-0.09)$ of the refreezing rate parameter of partitioned $T_{V}^{B}$ time series (1 April 2015 - 31 March 2019) iteratively fit to the sigmoid function (see Section 3). 
https://doi.org/10.5194/tc-2021-116

Preprint. Discussion started: 30 April 2021

(c) Author(s) 2021. CC BY 4.0 License.

766 2a; blue circle; Fig. 4a), where in situ perennial firn aquifer measurements have recently been collected

767 (Miller et al., 2017).

$768 \quad$ We calculate the absorption coefficient $\left(\kappa_{a}\right)$ in Eq. 7 using

769

770

$\kappa_{a}=-2 k_{o} \mathfrak{S}\left\{\sqrt{\varepsilon_{r}}\right\}$,

771

772

773

774

775

776

777

778

779

780

781

782

783

784

785

786

787

788

789

790

791

792

793

794

795

796

797

798

799

800

801

where $\Im\{\}$ represents the imaginary part. We calculate the complex dielectric constant of the saturated firn layer in Eq. 8 and Eq. 10 using the empirically derived models described in Tiuri et al., (1984). We set the volumetric fraction of meltwater to $m_{v}=1 \%$. We set the depth of the water-saturated firn layer in Eq. 7 to $d=1 \mathrm{~m}$. These values are consistent with typical lower frequency (e.g., $37 \mathrm{GHz}, 13.4 \mathrm{GHz}, 19 \mathrm{GHz}$ ) passive (e.g., Mote, et al. 1995; Abdalati and Steffen, 1997; Ashcraft and Long, 2006) and active (e.g., Hicks and Long, 2011) microwave algorithms used to detect seasonal surface melting over the GrIS. Using the results of Eq. 7, 8, 9, and 10, we calculate the firn saturation parameter threshold at $\xi_{T}=0.1$.

The first step in our adapted empirical algorithm is to map the extent of the percolation facies. For each rSIR grid cell within the ice sheet-masked extent of the GrIS, we smooth the corresponding $T_{V}^{B}$ time series (1 April 2015 - 31 March 2019) using a 14-observation (1 week) moving window. We extract the minimum vertically-polarized L-band brightness temperature $\left(T_{V, \min }^{B}\right)$, and the maximum vertically-polarized L-band brightness temperature $\left(T_{V, \max }^{B}\right)$. We set the physical temperature of the water-saturated firn layer to $T=273.15 \mathrm{~K}$, and the transmission angle to $\theta=40^{\circ}$. We then calculate the firn saturation parameter $(\xi)$ using Eq. 2. If the calculated firn saturation parameter exceeds the firn saturation parameter threshold, the rSIR grid cell is converted to a binary parameter to map the total extent of the percolation facies.

We note that smoothing $T_{V}^{B}$ time series will mask brief low-intensity seasonal surface melting that occurs in the high-elevation (> 2500 m) percolation facies, where seasonal meltwater is rapidly refrozen within the colder snow and firn layers (e.g., Fig. 4d). Thus, the calculated firn saturated parameter will not exceed the firn saturation parameter threshold, and these rSIR grid cells will be excluded from the algorithm. The exclusion of rSIR grid cells in the high-elevation percolation facies is not expected to have a significant impact on our results as our algorithm targets rSIR grid cells in areas that experience intense seasonal surface melting. The exclusion of rSIR grid cells will, however, slightly underestimate the mapped percolation facies extent.

The second step in our adapted empirical algorithm is to map the extent of perennial firn aquifer, ice slab, and perched firn aquifer areas over the percolation facies. For each rSIR grid cell within the mapped percolation facies extent, we normalize the corresponding $T_{V}^{B}$ time series (1 April 2015 - 31 March 2019) using Eq. $5\left(T_{V, N}^{B}(t)\right)$. We then extract the initial normalized vertically-polarized L-band brightness temperature, $\left(T_{V, N}^{B}\left(t_{\max }\right)\right)$ and the final normalized vertically-polarized L-band brightness temperature $\left(T_{V, N}^{B}\left(t_{\min }\right)\right)$, and partition $T_{V, N}^{B}(t)$ on the time interval $t \in\left[t_{\max }, t_{\min }\right]$. We smooth $T_{V, N}^{B}\left(t \in\left[t_{\max }, t_{\min }\right]\right)$ using a 56-observation ( 4 week) moving window. The sigmoid fit is then iteratively applied using Eq. 6. 
https://doi.org/10.5194/tc-2021-116

Preprint. Discussion started: 30 April 2021

(c) Author(s) 2021. CC BY 4.0 License.

802 Smoothing reduces the chi-squared error statistic when fitting $T_{V, N}^{B}\left(t \in\left[t_{\max }, t_{\min }\right]\right)$ to the sigmoid function.

803 We fix the initial normalized vertically-polarized L-band brightness temperature at $T_{V, N}^{B}\left(t_{\max }\right)=0.99$, which

804 provides a uniform parameter space in which the refreezing rate parameter ( $\zeta$ ) can be analyzed. Variability

805 in $T_{V, N}^{B}\left(t_{\max }\right)$ is controlled by the volumetric fraction of meltwater within the upper snow and firn layers of

806 the percolation facies, and is accounted for in the firn saturation parameter $(\xi)$, which is analyzed separately.

$807 T_{V, N}^{B}\left(t \in\left[t_{\max }, t_{\min }\right]\right)$ iteratively fit to the sigmoid function converge quickly (i.e., algorithm iterations I $\in$ [5, 808 15]), and observations are a good fit (i.e., chi squared error statistic is $\chi 2 \in[0,0.1]$ ).

$809 \quad$ Using the SMAP-derived $T_{V, N}^{B}\left(t_{\max }\right)$ and $T_{V, N}^{B}\left(t_{\min }\right)$, rather than the MODIS-derived initial 810 normalized vertically-polarized L-band brightness temperature at the surface freeze-up date $\left(T_{V, N}^{B}\left(t_{s f u}\right)\right)$, 811 and final normalized vertically-polarized L-band brightness temperature at the melt onset date $\left(T_{V, N}^{B}\left(t_{m o}\right)\right)$ 812 that were used in the empirical algorithm described in Miller et al., 2020 (e.g., Fig. 4), has several 813 advantages. They key advantage of this approach is that maps can be generated using $T^{B}$ imagery 814 collected from a single satellite, which simplifies the adapted empirical algorithm. Another advantage is that 815 unlike $T^{B}$ collected at shorter-wavelength thermal infrared frequencies (e.g., MODIS), $T^{B}$ collected at 816 longer wavelength microwave frequencies (e.g., SMAP) is not sensitive to clouds, which eliminates 817 observational gaps and cloud contamination, and provides more accurate time series partitioning and more 818 robust curve fitting. The mapped extent of Greenland's perennial firn aquifers generated by our adapted 819 empirical algorithm and by our empirical algorithm (Miller et al., 2020) are consistent (see Section 3).

820 We calibrate our adapted empirical algorithm using the AR- and MCoRDS-derived perennial firn 821 aquifer (2010-2017), ice slab (2010-2014), and perched firn aquifer (2010-2017) detections projected 822 separately on three NH EASE-Grids 2.0. For each rSIR grid cell with at least one detection, we extract the 823 corresponding maximum vertically-polarized L-band brightness temperature $\left(T_{V, \max }^{B}\right)$, the minimum 824 vertically-polarized L-band brightness temperature $\left(T_{V, \min }^{B}\right)$, the firn saturation parameter $(\xi)$, and the 825 refreezing rate parameter $(\zeta)$, and for each of the extracted SMAP-derived calibration parameters we 826 calculate the standard deviation $(\sigma)$. Similar to Miller et al., 2020, thresholds of $\pm 2 \sigma$ are set for each of the 827 extracted SMAP-derived calibration parameters in an attempt to eliminate peripheral rSIR grid cells near 828 the ice sheet edge and near the upper and lower boundaries of each sub-facie, where L-band emissions 829 can be influenced by morphological features, such as crevasses, superimposed and glacial ice, and 830 spatially integrated with emissions from rock, land, the ocean, and adjacent percolation facies and wet snow 831 facies areas. The SMAP-derived calibration parameter threshold intervals extracted from $T_{V}^{B}$ time series 832 that we use to map perennial firn aquifer, ice slab, and perched firn aquifer areas are given in Table 3 . We 833 apply the calibration to each rSIR grid cell within the percolation facies extent. If the extracted SMAP834 derived calibration parameters are within the threshold intervals, the rSIR grid cell is converted to a binary 835 parameter to map the total extent of each of these sub-facies.

836

837 
https://doi.org/10.5194/tc-2021-116

Preprint. Discussion started: 30 April 2021

(c) Author(s) 2021. CC BY 4.0 License.

Table 3. SMAP-derived calibration parameter threshold intervals (1 April 2015 - 31 March 2019) used for mapping perennial firn aquifer, ice slab, and perched firn aquifer areas.

\begin{tabular}{ccccc}
\hline & $\xi$ & $\boldsymbol{T}_{V, \boldsymbol{m a x}}^{B}$ & $\boldsymbol{T}_{V, \boldsymbol{m i n}}^{\boldsymbol{B}}$ & $\boldsymbol{\zeta}$ \\
\hline Perennial Firn Aquifers & $0.2-4$ & $200-275$ & $180-250$ & $-0.04--0.02$ \\
\hline Ice Slabs & $0.1-2$ & $170-260$ & $130-240$ & $-0.03--0.06$ \\
\hline Perched Firn Aquifers & $0.2-1.2$ & $200-260$ & $180-240$ & $-0.03--0.04$
\end{tabular}

840

Iteratively applying the sigmoid fit to $T_{V, N}^{B}\left(t \in\left[t_{\max }, t_{\min }\right]\right)$ over perched firn aquifer areas is a source of uncertainty in our adapted empirical algorithm. While the continuous logistic model is reasonable for the majority of exponentially decreasing temporal L-band signatures over the percolation facies, it is not optimal for exponentially decreasing temporal L-band signatures that transition to linearly decreasing on time scales of years following the surface freeze-up date. Especially multi-year linearly decreasing temporal L-band signatures over areas where perching occurs following intense seasonal surface melting and shallow water-saturated firn layers persist throughout the following freezing season as well as throughout weaker seasonal surface melting the following melting season (e.g., between September 2016 and May 2018 in Fig. 4b). Although $T_{V, N}^{B}\left(t \in\left[t_{\max }, t_{\min }\right]\right)$ over perched firn aquifer areas iteratively fit to the sigmoid function converge quickly (i.e., algorithm iterations $I \in[8,15]$ ), and observations appear to be a good fit (i.e., chi squared error statistic is $\chi 2 \in[0.06,0.1]$ ), simulated sigmoidal curves often asymptotically approach $T_{V, \min }^{B}$ too quickly, which underestimates the refreezing rate parameter $(\zeta)$ to values outside the SMAP-derived calibration parameter threshold intervals. Perched firn aquifer areas may alternatively be mapped as ice slab areas or percolation facies areas, which will underestimate or overestimate the mapped extent of each of these sub-facies.

Miller et al., 2020 cited significant uncertainty in the SMAP-derived perennial firn aquifer extent as a result of the lack of a distinct temporal L-band signature delineating the boundary between perennial firn aquifer areas and adjacent percolation facies areas. In this study, similar uncertainty exists in the SMAPderived perennial firn aquifer, ice slab, and perched firn aquifer extents. This uncertainty could, at least in part, be a result of the rSIR algorithm. An rSIR grid cell corresponds to the weighted average of $T_{V}^{B}$ over SMAP's antenna footprint (Long et al., 2020). The weighting is the grid cell's spatial response function (SRF), which is $\sim 18 \mathrm{~km}$ (i.e. the effective resolution) in diameter. The SRF is centered on the rSIR grid cell. Since the effective resolution (i.e., size of the $3 \mathrm{~dB}$ contour of the SRF) is less than the rSIR grid cell spacing, rSIR grid cell SRF's overlap and the grid cells $T_{V}^{B}$ values are not statistically independent. This uncertainty, however, could also have a geophysical basis, as it is unlikely that the boundaries between sub-facies (perennial firn aquifers, ice slabs, and perched firn aquifers) as well as between facies (percolation facies, dry snow facies, wet snow facies) are distinct. The thickness of the water-saturated firn layer or ice slab may thin and taper-off at the periphery, and sub-facies and facies may become spatially scattered and 
869 merge together. Over SMAP's $\sim 18 \mathrm{~km}$ footprint, spatially integrated L-band emissions may also result in a smooth transition between temporal L-band signatures.

871 The limited extent (AR, $15 \mathrm{~m} \times 20 \mathrm{~m}$; MCoRDS, $14 \mathrm{~m} \times 40 \mathrm{~m}$ ) of the airborne ice-penetrating radar detections as compared to the rSIR grid cell extent $(3.125 \mathrm{~km} \times 3.125 \mathrm{~km})$ and the effective resolution $(\sim 18$ $\mathrm{km}$ ) of the SMAP enhanced-resolution $T_{V}^{B}$ imagery is also cited in Miller et al., 2020 as a source of uncertainty in the empirical algorithm. In this study, similar uncertainty exists in our adapted empirical algorithm. The total rSIR grid cell extent with radargram coverage is less than $2 \%$, which means that $\sim 98 \%$ of the total rSIR grid cell extent with radargram coverage, from which the SMAP-derived calibration parameter threshold intervals are extracted, is unknown. Calculating the total rSIR grid cell extent where detections are absent along OIB flight lines and statistically integrating this calculation into the multi-year calibration technique may help reduce the uncertainty, particularly the significant uncertainty in the interannual variability, which we have yet to resolve. A sensitivity analysis suggests that even small changes in any of the SMAP-derived calibration parameter threshold intervals (i.e., several $\mathrm{K}$ for $T_{V, \min }^{B}$, and $T_{V, \max }^{B}$, several tenths of a percentage point for $\xi$, and several hundredths of a percentage point for $\zeta$ ) can result in variability in the mapped extents of hundreds of square kilometers, and boundary transitions between perennial firn aquifer, ice slab, and perched firn aquifer areas. Thus, the mapped extent of each of these sub-facies of the broader percolation facies should simply be considered an initial result demonstrating the potential of our adapted empirical algorithm for future work.

887

888

\section{Results and Discussion}

The SMAP-derived maximum vertically-polarized L-band brightness temperature values generated by our adapted empirical algorithm range from between $T_{V, \max }^{B}=150 \mathrm{~K}$ and $275 \mathrm{~K}$, and the minimum verticallypolarized L-band brightness temperature values range from between $T_{V, \min }^{B}=130 \mathrm{~K}$ and 250 . These values are consistent with the range of $T_{V, \max }^{B}$ and $T_{V, \min }^{B}$ values given in the temporal L-band signature analysis (Section 2.4.2; Table 2). Firn saturation parameter values range from between $\xi=0.1$ and 4.0. Refreezing rate parameter values range from between $\zeta=-0.09$ and -0.01 . The lower bound $(\zeta=-0.09)$ of the refreezing rate parameter observed over the percolation facies is significantly higher than the predicted lower bound $(\zeta=-1)$ in our example set of simulated sigmoidal curves (black line, Fig. 6).

898 The SMAP-derived perennial firn aquifer (blue shading), ice slab (cyan shading), perched firn aquifer (green shading), and percolation facies (purple shading) extents (2015-2019) generated by our

900 adapted empirical algorithm are shown in Figs. 7a-9a, and are summarized in Table 4. The percolation 901 facies extent $\left(\sim 5.8 \times 10^{5} \mathrm{~km}^{2}\right)$ generated by our adapted empirical algorithm is mapped at elevations 902 between $\sim 500$ m.a.s.I. and 3500 m.a.s.l., and extends over $\sim 32 \%$ of the GrlS extent $\left(\sim 1.8 \times 10^{6} \mathrm{~km}^{2}\right)$. The 903 perennial firn aquifer extent $\left(64,000 \mathrm{~km}^{2}\right)$ is mapped at elevations between $\sim 600$ m.a.s.l and 2600 m.a.s.l., 904 and extends over $\sim 11 \%$ of the percolation facies extent and $\sim 4 \%$ of the GrIS extent. High $T_{V, \max }^{B}, T_{V, \min }^{B}$, 

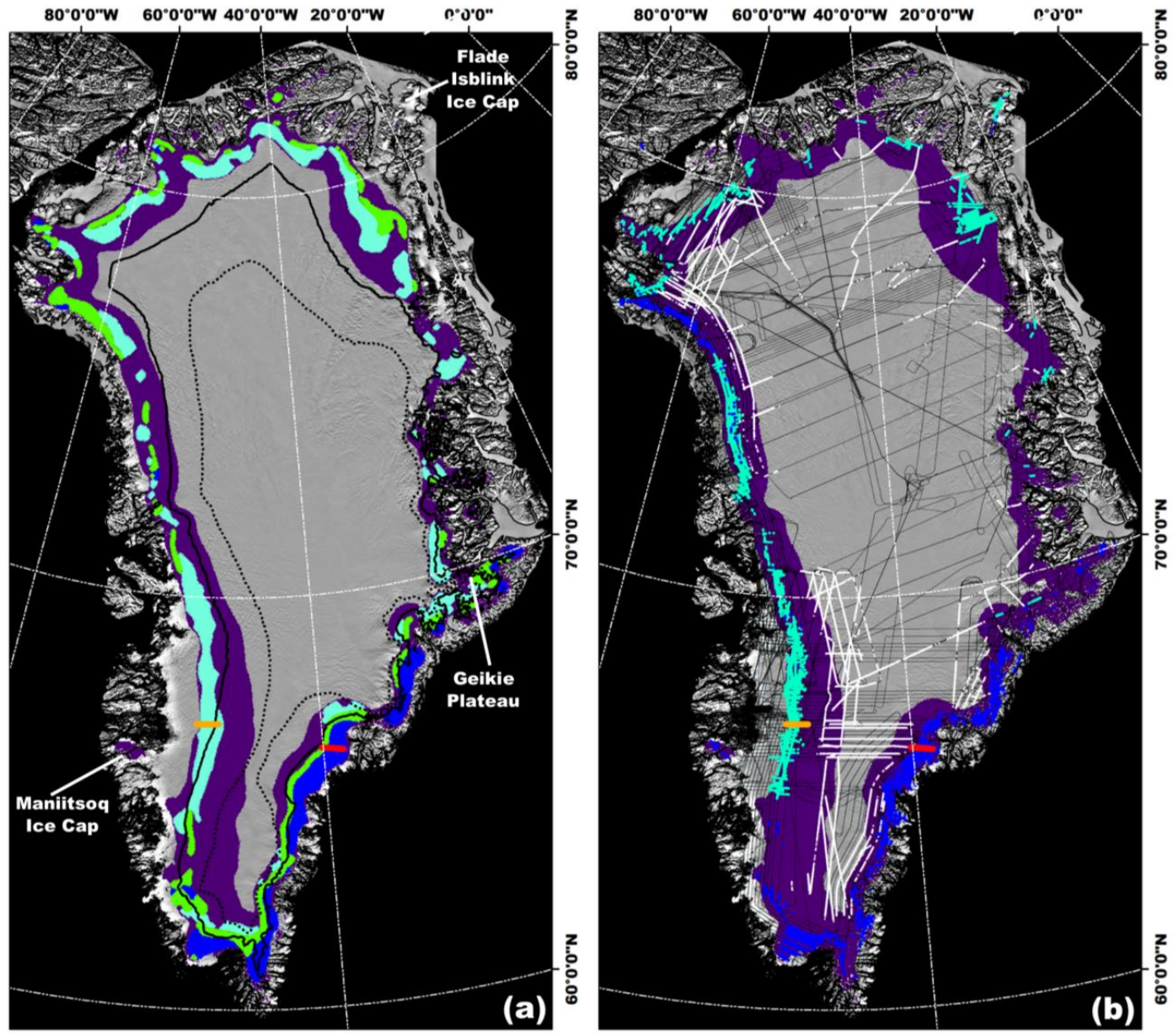

\section{Figure 7}

907 (a) The SMAP-derived perennial firn aquifer (blue shading), ice slab (cyan shading), perched firn aquifer 908 (green shading), and percolation facies (purple shading) extents (2015-2019) generated by the adapted 909 empirical algorithm overlaid on the 2015 MODIS Mosaic of Greenland image map (Haran et al., 2018). The 910 black line is the 2000 m.a.s.l. contour, and the black dotted line is the 2500 m.a.s.l. contour (Howat et al., 911 2014). (b) The SMAP-derived extents are overlaid with AR-and MCoRDS-derived 2010-2017 perennial firn 912 aquifer (blue shading; Miège et al., 2016), 2010-2014 ice slab (cyan shading; McFerrin et al., 2019), and 9132012 spatially coherent melt layer (white shading; Culberg et al., 2021) detections along OIB flight lines 914 (black lines). Overlapping perennial firn aquifer and ice slab detections are interpreted as perched firn 915 aquifer areas. The red line is AR radargram profile along perennial firn aquifer transect A-B (Fig. 3a). The 916 orange line is $A R$ radargram profile along ice slab transect C-D (Fig. 3b). 

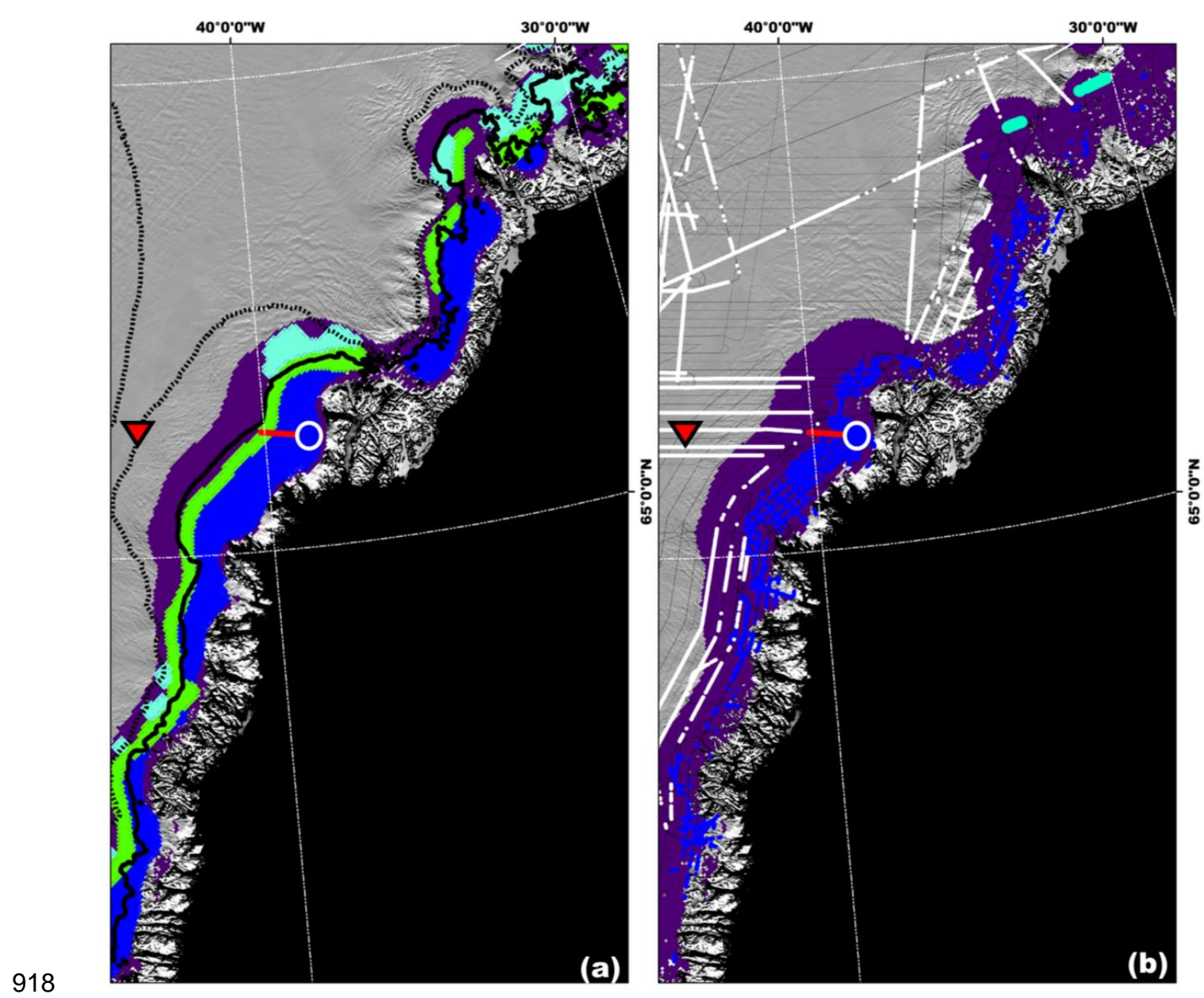

\section{Figure 8}

920 (a) The SMAP-derived perennial firn aquifer (blue shading), ice slab (cyan shading), perched firn aquifer 921 (green shading), and percolation facies (purple shading) extents (2015-2019) generated by the adapted empirical algorithm over south eastern Greenland (Fig. 1c; zoom area in red box) overlaid on the 2015 MODIS Mosaic of Greenland image map (Haran et al., 2018). The solid black line is the 2000 m.a.s.l. contour, and the black dotted line is the 2500 m.a.s.l. contour (Howat et al., 2014). (b) The SMAP-derived percolation facies extent is overlaid with AR- and MCoRDS-derived 2010-2017 perennial firn aquifer (blue shading; Miège et al., 2016), 2010-2014 ice slab (cyan shading; McFerrin et al., 2019), and 2012 spatially coherent melt layer (white shading; Culberg et al., 2021) detections along OIB flight lines (black lines). Overlapping perennial firn aquifer and ice slab detections are interpreted as perched firn aquifer areas. The red line is AR radargram profile along perennial firn aquifer transect $A-B$ (Figs. 1; 3a). The blue circle is a perennial firn aquifer area (Figs. 3a; 4a). The red triangle is a high-elevation ( 2500 m.a.s.l.) percolation facies area (Figs. 4d). 

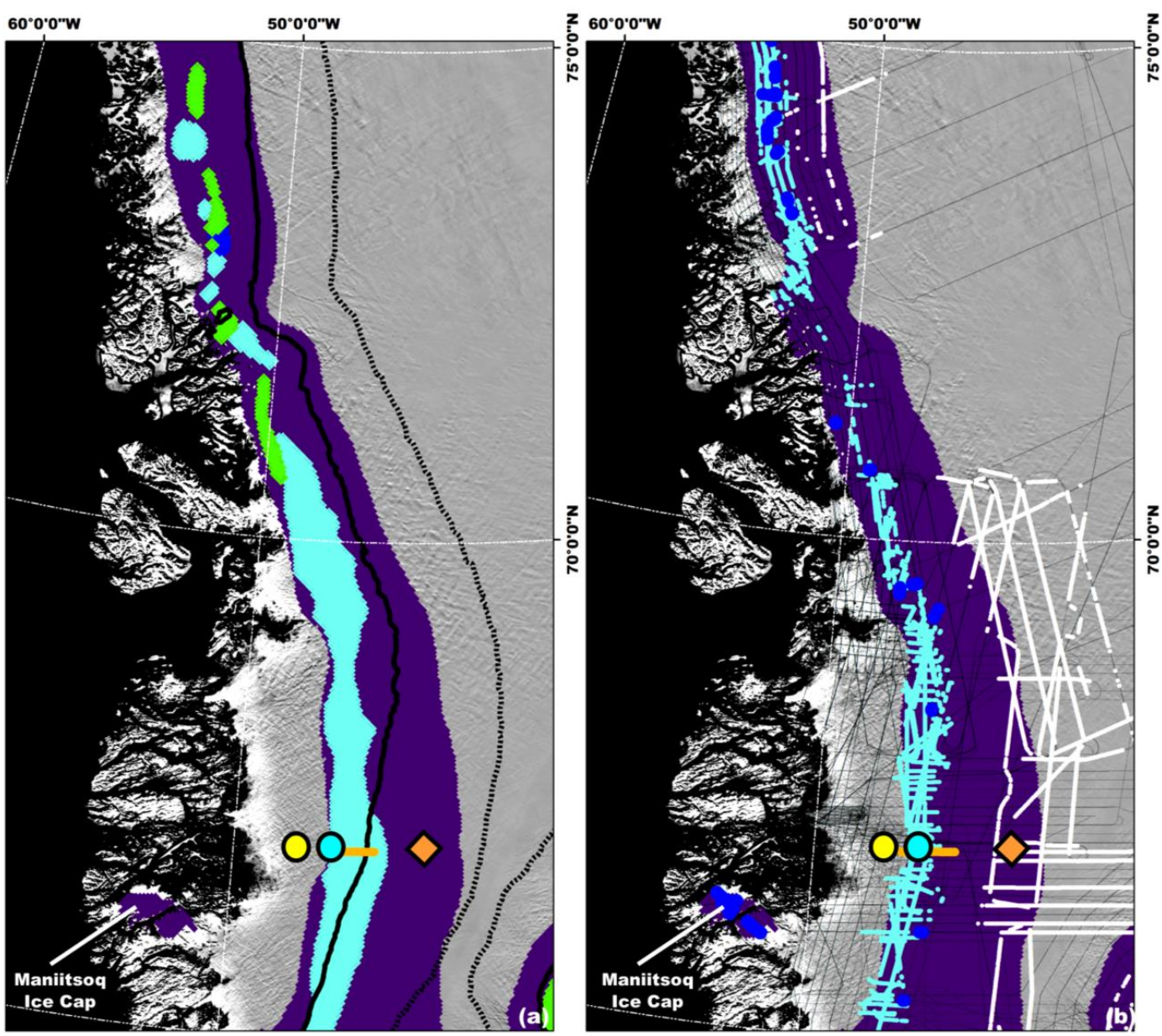

\section{Figure 9}

934 (a) The SMAP-derived perennial firn aquifer (blue shading), ice slab (cyan shading), perched firn aquifer (green shading), and percolation facies (purple shading) extents (2015-2019) generated by the adapted empirical algorithm over south western Greenland (Fig. 1C; zoom area in red box) overlaid on the 2015 MODIS Mosaic of Greenland image map (Haran et al., 2018). The solid black line is the 2000 m.a.s.l. contour, and the black dotted line is the 2500 m.a.s.l. contour (Howat et al., 2014). (b) The SMAP-derived percolation facies extent is overlaid with AR- and MCoRDS-derived 2010-2017 perennial firn aquifer (blue shading; Miège et al., 2016), 2010-2014 ice slab (cyan shading; McFerrin et al., 2019), and 2012 spatially coherent melt layer (white shading; Culberg et al., 2021) detections along OIB flight lines (black lines).

942 Overlapping perennial firn aquifer and ice slab detections are interpreted as perched firn aquifer areas. The 943 orange line is AR radargram profile along ice slab transect $C-D$ ( Figs 1; 3b). The cyan circle is a perched 944 firn aquifer area (Figs. 3b; 4b). The orange diamond is a percolation facies area (Fig. 4C). The yellow circle 945 is a superimposed ice area (Fig. 4e). 
https://doi.org/10.5194/tc-2021-116

Preprint. Discussion started: 30 April 2021

(c) Author(s) 2021. CC BY 4.0 License.

(c) (i)

$946 \xi$, and $\zeta$ values within the perennial firn aquifer extent indicates the presence of thicker water-saturated

947 firn layers with larger volumetric fractions of meltwater that are radiometrically warm during both the melting

948 and freezing seasons and have extended refreezing rates. The ice slab extent $\left(76,000 \mathrm{~km}^{2}\right)$ is mapped at

949 elevations between $\sim 800$ m.a.s.I and 2700 m.a.s.l., and extends over $\sim 13 \%$ of the percolation facies extent

950 and $\sim 4 \%$ of the GrIS extent. As compared to perennial firn aquifer areas, decreased $T_{V, \max }^{B}, T_{V, \min }^{B}, \xi$ and

$951 \zeta$ values indicates the presence of thinner water-saturated firn layers with lower volumetric fractions of

952 meltwater that are radiometrically colder and have slightly more rapid refreezing rates. The SMAP-derived

953

954

955

956

957

958

959

960

961

962

963

964

965

966

967

968

969

970

Table 4. The SMAP-derived perennial firn aquifer, ice slab, and perched firn aquifer extents (2015-2019) over the percolation facies and the GrIS, and the elevation range at which they are mapped.

\begin{tabular}{cccc}
\hline & $\begin{array}{c}\text { Percolation Facies Extent } \\
\text { (\%) }\end{array}$ & $\begin{array}{c}\text { Ice Sheet Extent } \\
\text { (\%) }\end{array}$ & $\begin{array}{c}\text { Elevation Range } \\
\text { (m.a.s.I.) }\end{array}$ \\
\hline Perennial Firn Aquifers & 11 & 4 & $600-2600$ \\
\hline Ice Slabs & 13 & 4 & $800-2700$ \\
\hline Perched Firn Aquifers & 5 & $<1$ & $600-2700$
\end{tabular}

971

972

973

Figs. 7b-9b shows perennial firn aquifers (blue shading), ice slabs (cyan shading), and spatially coherent melt layers (white shading) detected by airborne ice-penetrating radar surveys (2010-2017)

975 where perennial firn aquifer and ice slab detections overlap. The SMAP-derived perennial firn aquifer extent

976 mapped in southern, and south and central eastern Greenland is consistent with the AR- and MCoRDS- 
https://doi.org/10.5194/tc-2021-116

Preprint. Discussion started: 30 April 2021

(C) Author(s) 2021. CC BY 4.0 License.

977 geophysical derived perennial firn aquifer detections (2010-2017), except in north western Greenland

978 where perched firn aquifers are alternatively mapped. The SMAP-derived ice slab extent mapped in

979 western, central and north eastern, and northern Greenland is generally consistent with the spatial patterns

980 of the AR-derived ice slab detections (2010-2014), however, is significantly expanded upslope in each of

981 these areas. We note that the AR-derived ice slab detections are limited in space and time, particularly in

982 northern Greenland, with a time interval as large as nine years between the airborne ice penetrating radar

983 surveys and the SMAP enhanced-resolution $T_{V}^{B}$ imagery used in the adapted empirical algorithm (i.e., 2010

984 to 2019). In western and northern Greenland, the 2015 melting season was especially intense (Tedesco et

985 al., 2016). And, in northern Greenland, the ablation facies have recently increased in extent (2010-2019;

986 Noël et al., 2019), and supraglacial lakes have recently advanced inland (2014-2019; Turton et al., 2021),

987 indicating a likley geophysical basis for the observed upslope expansion. In central and north eastern, and

988 northern Greenland, perched firn aquifers are often alternatively mapped. Additional smaller ice slab areas

989 are mapped in south and south eastern (Figs. 9a; 9b) Greenland. The scattered SMAP-derived perched

990 firn aquifer extent mapped in north western and central eastern Greenland is fairly consistent with the

991 sparse AR- and MCoRDS-derived perched firn aquifer detections (2010-2017), however, in central western

992 Greenland (Figs. 9a; 9b) ice slab areas are alternatively mapped. Expansive additional perched firn aquifer

993 areas are mapped in southern, and south and central eastern Greenland. These areas are often coincident

994 with spatially coherent melt layer detections, particularly in south eastern Greenland (Figs. 8a, 8b). Neither

995 perennial firn aquifer, ice slab, nor perched firn aquifer areas are mapped on the Maniitsoq and Flade Isblink

996 Ice Caps. Over these two small ice caps, L-band emissions spatially integrated with emissions from rock,

997 land, the ocean, and adjacent percolation facies and wet snow facies areas result in SMAP-derived

998 calibration parameter values outside the defined intervals for each of these sub-facies.

999 We infer that the SMAP-derived perched firn aquifer extent represents L-band emissions from: (1)

1000 spatially expansive, relatively shallow water-saturated firn layers with lower volumetric fractions of

1001 meltwater as compared to perennial firn aquifer areas. These shallow water-saturated firn layers transiently

1002 form on top of buried ice slabs, spatially coherent melt layers, or other semi-impermeable layers that have

1003 previously formed within the upper snow and firn layers of the percolation facies, as shown in Figs. 7-8. Or,

1004 (2) spatially scattered deeper water-saturated firn layers with larger volumetric fractions of meltwater (i.e.,

1005 perennial firn aquifers) that are spatially integrated with L-band emissions from adjacent ice slabs,

1006 percolation facies, and/or wet snow facies areas. These areas are observed as shallow water-saturated firn

1007 layers with lower volumetric fractions of meltwater over SMAP's $\sim 18 \mathrm{~km}$ footprint (i.e., the effective

1008 resolution). Or, (3) a combination of these englacial firn hydrological features, which is a likely scenario

1009 over many perched firn aquifers areas. This is particularly likely in north western Greenland, where airborne

1010 ice penetrating radar surveys consistently detect perennial firn aquifers; however, the SMAP-derived extent

1011 indicates perched firn aquifer areas (Fig. 7).

1012 
https://doi.org/10.5194/tc-2021-116

Preprint. Discussion started: 30 April 2021

(C) Author(s) 2021. CC BY 4.0 License.

1013 Shallow buried supraglacial lakes have recently been identified within the percolation facies of 1014 western, northern, and north and central eastern Greenland using airborne ice penetrating radar surveys 1015 (Koenig et al., 2015) and satellite synthetic aperture radar imagery (Miles et al., 2017; Schröder et al., 2020; 1016 Dunmire et al., 2021). These buried supraglacial lakes are within the SMAP-derived perennial firn aquifer, 1017 ice slab, and perched firn aquifer extents, however, they are not expected to significantly influence L-band 1018 emissions in these areas for two reasons: (1) as compared to SMAP's 18 km footprint, the mean extent 1019 of buried supraglacial lakes is limited (less than $\sim 1 \mathrm{~km}^{2}$ ), and they are sparsely distributed in perennial firn 1020 aquifer, ice slab, and perched firn aquifer areas (Dunmire et al., 2021). (2) Supraglacial lakes form during 1021 the melting season as a result of meltwater storage in topographic depressions at the ice sheet surface 1022 (Echelmeyer et al. 1991). Similar to subglacial lakes (Jezek et al., 2015) and perennial firn aquifers (Miller 1023 et al., 2020), supraglacial lakes represent radiometrically cold subsurface meltwater reservoirs. Upwelling 1024 L-band emissions from deeper firn layers, glacial ice, and the underlying bedrock are effectively blocked by 1025 high reflectivity and attenuation at the impermeable layer-lake bottom interface. This results in a low 1026 observed $T_{V}^{B}$ at the upper surface of meltwater stored within supraglacial lakes. During the freezing season, 1027 the upper surface of meltwater stored within supraglacial lakes refreezes and forms a partial or solid-ice 1028 cap that is sometimes buried by snow accumulation (Koenig et al., 2015). Airborne ice penetrating radar 1029 surveys in April and May between 2009 and 2012 suggest the mean depth to the upper surface of meltwater 1030 stored within buried supraglacial lakes is $\sim 2 \mathrm{~m}$ (Koenig et al., 2015). As previously noted, over perennial 1031 firn aquifer, ice slab, and perched firn aquifer areas, L-band emissions from the radiometrically warm upper 1032 snow and firn layers decrease on variable time scales during the freezing season as embedded ice 1033 structures slowly refreeze at increased depths below the ice sheet surface and induce strong volume 1034 scattering (Rignot et al., 1993; Rignot 1995). $T_{V}^{B}$ can decrease by as much as $\sim 50 \mathrm{~K}$ during the freezing 1035 season (e.g., Fig. 4a), representing the descent of the upper surface of stored meltwater by tens of meters 1036 (Miège et al., 2016). However, over buried supraglacial lakes, L-band emissions from the refreezing partial 1037 or solid-ice cap, which is smooth relative to the L-band wavelength $(\sim 21 \mathrm{~cm})$, induce surface scattering. As 1038 a result, $T_{V}^{B}$ decreases over buried supraglacial lakes are negligible. Thus, over SMAP's $\sim 18$ km footprint, 1039 water-saturated firn layers dominate L-band emissions over the percolation facies of the GrIS.

$1040 \quad$ The SMAP-derived perennial firn aquifer extent $\left(\sim 64,000 \mathrm{~km}^{2}\right)$ generated by our adapted empirical 1041 algorithm and the multi-year (2010-2017) calibration technique is consistent with the extent $\left(\sim 66,000 \mathrm{~km}^{2}\right)$ 1042 generated by the previously developed empirical algorithm and the single-coincident year (2016) calibration 1043 technique described in Miller et al., 2020. The SMAP-derived perennial firn aquifer extent is generally 1044 consistent with previous C-band $(5.3 \mathrm{GHz})$ satellite radar scatterometer-derived perennial firn aquifer 1045 extents mapped using the Advanced SCATterometer (ASCAT) on the European Organization for the 1046 Exploitation of Meteorological Satellites (EUMETSAT) Meteorological Operational A (MetOp-A) satellite 1047 (2009-2016, 52 000-153000 km²; Miller, 2019), and the Active Microwave Instrument in radar 1048 scatterometer mode (ESCAT) on ESA's European Remote Sensing (ERS) satellite series (1992-2001, $1049 \sim 37$ 000-64 $000 \mathrm{~km}^{2}$; Miller, 2019) as well as the C-band (5.4 GHz) synthetic aperture radar-derived extent 
1050

1051

1052

1053

1054

1055

1056

1057

1058

1059

1060

1061

1062

1063

1064

1065

1066

1067

1068

1069

1070

\begin{tabular}{cccc}
\hline & $\begin{array}{c}\text { Perennial Firn Aquifer Extent } \\
\left.\mathbf{( k m}^{2}\right)\end{array}$ & $\begin{array}{c}\text { Ice Slab Extent } \\
\left.\mathbf{( k m}^{2}\right)\end{array}$ & $\begin{array}{c}\text { Perched Firn Aquifer Extent } \\
\left.\mathbf{( k m}^{2}\right)\end{array}$ \\
\hline $\mathbf{2 0 1 5 - 2 0 1 9}$ & 66,000 & 76,000 & 37,000 \\
\hline $\mathbf{2 0 1 5 - 2 0 1 6}$ & 63,000 & 23,000 & 17,000 \\
\hline $\mathbf{2 0 1 6 - 2 0 1 7}$ & 69,000 & 48,000 & 38,000 \\
\hline $\mathbf{2 0 1 7 - 2 0 1 8}$ & 73,000 & 27,000 & 20,000 \\
\hline $\mathbf{2 0 1 8 - 2 0 1 9}$ & 70,000 & 38,000 & 26,000
\end{tabular}

mapped using ESA's Sentinel-1 satellite (2014-2019, 54000 km²; Brangers et al., 2020). The exception is the ASCAT-derived perennial firn aquifer extent (2012-2013, 153,000 km²; Miller et al., 2019) mapped following the anomalous 2012 melting season (Nghiem et al., 2012) in which significant changes in the dielectric and geophysical properties that influence radar backscatter and the temporal C-band signatures occurred. The unreasonably expansive (i.e., more than twice the mean) mapped extent is a result of ASCAT'S shallow ( several meters) C-band penetration depth (Jezek et al., 1994), and the simple threshold-based algorithm that was not calibrated for an extreme melting season that included saturation of the upper snow and firn layers of the dry snow facies and percolation facies with relatively large volumetric fractions of meltwater (Miller et al., 2019). Water-saturated firn layers had extended refreezing rates, however, seasonal meltwater was not stored at depth. Spatially coherent melt layers were alternatively formed in many of the mapped areas (Culberg et al., 2021). The SMAP-derived ice slab extent $\left(\sim 76,000 \mathrm{~km}^{2}\right)$ is also consistent with previous AR-derived ice slab extents $\left(2010-2014, \sim 64,800 \mathrm{~km}^{2}-69,400\right.$ $\mathrm{km}^{2}$; McFerrin et al., 2019).

Although we simply consider our mapped extents a high-probability area for preferential formation, the maps generated by our adapted empirical algorithm and the multi-year (2010-2017) calibration technique for individual years suggest interannual variability in perennial firn aquifer, ice slab, and perched firn aquifer extents, which is summarized in Table 5. Our results demonstrate reasonable sensitivity to variability in the dielectric and geophysical properties that influence the radiometric temperature and temporal L-band signatures, even during the extreme 2015 melting season (Tedesco et al., 2016).

Table 5 The SMAP-derived perennial firn aquifer, ice slab, and perched firn aquifer extents (2015-2019).

1071

1072

1073

1074

1075 
https://doi.org/10.5194/tc-2021-116

Preprint. Discussion started: 30 April 2021

(C) Author(s) 2021. CC BY 4.0 License.

(c) (i)

\section{Summary and Future Work}

1077 L-band satellite microwave sensors - including NASA's L-band SMAP mission - represent a relatively new

1078 Earth-observation tool that has exceptional capabilities for cryospheric applications. Especially, mapping

1079 englacial and subglacial hydrological features at depths of $\sim$ tens to hundreds of meters beneath the surface

1080 of Earth's polar ice sheets. In this study, for the first time, we have exploited this capability and demonstrated

1081 the novel use of the L-band microwave radiometer on NASA's SMAP satellite for mapping perennial firn

1082 aquifers, ice slabs, and perched firn aquifers together as a continuous system over the percolation facies

1083 of the GrIS. We have also demonstrated that SMAP enhanced-resolution L-band $T_{V}^{B}$ imagery can effectively

1084 resolve percolation facies features that are not effectively resolved in conventionally processed SMAP L-

1085 band $T_{V}^{B}$ imagery (e.g., Fig. 1). We have adapted our previously developed empirical algorithm (Miller et

1086 al., 2020) by expanding our analysis of spatiotemporal differences in SMAP enhanced-resolution $T_{V}^{B}$

1087 imagery and temporal L-band signatures over the GrIS. We have used this analysis to derive a firn

1088 saturation parameter from a simple two-layer L-band geophysical-brightness temperature model. And, we

1089 have used the firn saturation parameter to map the extent of the percolation facies. We have found that by

1090 correlating maximum and minimum $T_{V}^{B}$ values, the firn saturation parameter, and the refreezing rate

1091 parameter with perennial firn aquifer, ice slab, and perched firn aquifer detections identified via NASA's OIB

1092 campaigns that we can calibrate our previously developed empirical algorithm (Miller et al., 2020) to map

1093 plausible extents.

1094 We note that significant uncertainty exists in the mapped extents as a result of (1) correlating the

1095 SMAP-derived parameters with airborne ice-penetrating radar detections that are not coincident in time, (2)

1096 the lack of a distinct temporal L-band signature delineating the boundary between each of the mapped sub-

1097 facies within the broader percolation facies, and (3) the much more limited extent of the airborne ice-

1098 penetrating radar detections as compared to the rSIR grid cell extent, as well as the effective resolution of

1099 the SMAP enhanced-resolution $T_{V}^{B}$ imagery. Additional uncertainty exists in the perched firn aquifer extent

1100 as a result of fitting L-band signatures to the continuous logistic model, which is not optimal for these specific

1101 sub-facies.

$1102 \quad$ Miller et al., (2020) normalized SMAP enhanced-resolution $T_{V}^{B}$ time series and converted the

1103 exponential rate of $T_{V}^{B}$ decrease over perennial firn aquifer areas to a binary parameter to map extent. In

1104 this study, we have converted the SMAP-derived parameters to binary parameters to map the extent of

1105 perennial firn aquifer, ice slab, and perched firn aquifer areas. Moreover, we have included additional

1106 analysis of the spatiotemporal differences in maximum and minimum $T_{V}^{B}$ values, the firn saturation

1107 parameter, and the refreezing rate parameter. We have shown that spatiotemporal differences in the

1108 SMAP-derived parameters are consistent with our assumption of spatiotemporal differences in the englacial

1109 hydrology and thermal characteristics of firn layers at depth. Particularly, our assumption that latent heat

1110 release influences temporal L-band signatures within the percolation facies of the GrIS. This includes

1111 continuous latent heat release via the slow refreezing of the deeper firn layers in perennial and perched firn

1112 aquifer areas that are saturated with large volumetric fractions of meltwater. And, latent heat release that 
https://doi.org/10.5194/tc-2021-116

Preprint. Discussion started: 30 April 2021

(C) Author(s) 2021. CC BY 4.0 License.

1113 occurs throughout the percolation facies via more rapid refreezing of seasonal meltwater by the descending

1114 winter cold wave, and the subsequent formation of embedded ice structures, including ice slabs and

1115 spatially coherent melt layers, within the upper snow and firn layers.

$1116 \quad$ Future work will focus on simulating maximum and minimum $T_{V}^{B}$, the firn saturation parameter, and

1117 the refreezing rate parameter as well as temporal L-band signatures observed over perennial firn aquifer, 1118 ice slab, and perched firn aquifer areas within the percolation facies of the GrIS for a wide range of 1119 geophysical properties. Significant interannual variability in the dielectric and geophysical properties that 1120 seasonally influence the radiometric temperature and temporal L-band signatures can occur, particularly 1121 following extreme melting seasons, such that it is critical that these properties are understood and 1122 considered in any given year. To better interannual variability as well as other geophysical properties, we 1123 will interpret our results together with climatological parameters, such as snow accumulation, liquid water 1124 content, temperature, and surface mass balance, and over the GrIS simulated using the Regional 1125 Atmospheric Climate Model (RACMO2.3p2; Noël et al., 2018). Additionally, we will simulate the distinct 1126 temporal L-band signatures observed over spatially coherent melt layers in the upper snow and firn layers 1127 of the dry snow facies and percolation facies of the GrIS recently identified via MCoRDS flown by NASA's 1128 OIB campaigns (Culberg et al., 2021) following the anomalous 2012 melting season (Nghiem et al., 2012) 1129 and as well as explore the potential for mapping the extent of these near-surface englacial hydrological 1130 features using satellite L-band microwave radiometry. Nghiem et al., (2003) previously demonstrated 1131 mapping spatially coherent melt layers that were formed following the anomalous 2002 melting season 1132 (Steffen et al., 2004) using similar signatures observed in Ku-band radar backscatter time series collected 1133 by the SeaWinds radar scatterometer that was flown on NASA's QuikSCAT satellite (Tsai et al., 2000). 1134 Combining multi-layer depth-integrated L-band geophysical-brightness temperature models (e.g., Jezek et 1135 al., 2015) that include embedded ice structure parametrizations (e.g., Jezek et al., 2018) with models of 1136 depth-dependent geophysical parameters can lead to an improved understanding of the extremely complex 1137 and very poorly described physics controlling L-band emissions over the percolation facies of the GrIS. For 1138 L-band emissions over perennial firn aquifer, ice slab, perched firn aquifer, and spatially coherent melt layer 1139 areas, the key geophysical parameters include atmospheric temperature forcing, physical temperature 1140 versus depth, latent heat, snow accumulation, the volumetric fraction and depth of meltwater, and the 1141 volumetric fraction and geometric configuration of embedded ice structures. The development of more 1142 sophisticated empirical algorithms that incorporate multi-layer depth-integrated L-band geophysical1143 brightness temperature models that are constrained by in situ measurements can help reduce the 1144 significant uncertainty in the current mapped extents, and provide more accurate boundaries delineating 1145 each of these sub-facies within the broader percolation facies that can be used to quantify variability in 1146 extent. As Greenland's climate continues to warm, and seasonal surface melting increases in extent, 1147 intensity, and duration, quantifying the possible rapid expansion of each of these sub-facies using satellite 1148 L-band microwave radiometry has significant implications for understanding ice sheet-wide variability in 
1149 englacial firn hydrology resulting in meltwater-induced hydrofracturing and accelerated ice flow as well as 1150 high-elevation run-off that can impact the mass balance and stability of the GrIS.

1151 The results presented in this study demonstrate the outstanding potential of L-band satellite 1152 microwave sensors for mapping englacial firn hydrological features within the percolation facies of the GrIS 1153 that can be extended to forthcoming satellite missions, such as the NASA-ISRO SAR mission (NISAR), 1154 ESA's Copernicus Imaging Microwave Radiometer (CIMR) mission, ESA's Copernicus Radar Observation 1155 System for Europe in L-band (ROSE-L) mission, and candidate missions, such as ESA's Earth Explorer 10 1156 Cryorad mission.

1157

1158

\section{Data Availability}

SMAP enhanced-resolution L-band $T_{V}^{B}$ imagery (2015-2019) have been produced as part of the NASA

1160 Science Utilization of SMAP project and are available at https://doi.org/10.5067/QZ3WJNOUZLFK (Brodzik et al., 2019). The NASA MEaSUREs Greenland Ice Mapping Project (GIMP) Land Ice and Ocean Classification Mask, Version 1, is available at https://doi.org/10.5067/B8X58MQBFUPA (Howat, 2017), and the Digital Elevation Model, Version 1, is available at https://nsidc.org/data/nsidc-0645/versions/1 (Howat et al., 2015). The coastline data are available from GSHHG - A Global Self-consistent, Hierarchical, Highresolution Geography Database https://doi.org/10.1029/96JB00104 (Wessel and Smith, 1996). Ice surface temperature imagery (2015-2019) have been produced as part of the Multilayer Greenland Ice Surface Temperature, Surface Albedo, and Water Vapor from MODIS V001 data set and are available at https://doi.org/10.5067/7THUWT9NMPDK (Hall and DiGirolamo, 2019). OIB AR- and MCoRDS-derived perennial firn aquifers detections (2010-2017) are available at 1170 https://arcticdata.io/catalog/view/doi:10.18739/A2985M (Miège et al., 2016). OIB AR-derived ice slab detections (2010-2014) are available at https://doi.org/10.6084/m9.figshare.8309777 (McFerrin et al., 2019). OIB AR-derived spatially coherent melt layer detections (2017) are available at (https://doi.org/10.18739/A2736M33W) (Culberg et al., 2021). OIB AR L1B Geolocated Radar Echo

1174 Strength Profiles, Version 2, are available at, https://doi.org/10.5067/0ZY1XYHNIQNY (Paden et al., 2018). 1175 NASA MEaSUREs MODIS Mosaic of Greenland (MOG) 2015 Image Map, Version 2, is available at 1176 https://nsidc.org/data/NSIDC-0547/versions/2 (Haran et al., 2018). SMAP-derived perennial firn aquifer, ice 1177 slab, and perched firn aquifer extents are available from JZM upon request.

\section{Author Contributions}

JZM initiated the study, adapted the empirical model, performed the analyses, and wrote the manuscript. $\mathrm{RC}$ processed and interpreted the OIB AR radargram profiles. $\mathrm{RC}$ and DMS provided the spatially coherent melt layer detections. All authors participated in discussions and reviewed manuscript drafts. 
https://doi.org/10.5194/tc-2021-116

Preprint. Discussion started: 30 April 2021

(C) Author(s) 2021. CC BY 4.0 License.

1186 The authors declare that they have no conflict of interest.'

\section{Financial Support}

1189 JZM, DGL, and MJB are supported by the NASA SMAP science team (no. 80NSSC20K1806), and by the 1190 NASA Cryospheric Science Program (no. 80NSSC18K1055 and no. 80NSSC21K0749) under grants to the 1191 University of Colorado and Brigham Young University. RC is supported by a National Defense Science and 1192 Engineering Graduate Fellowship. RC and DMS are supported in part by NASA (no. NNX16AJ95G and 1193 NSF (no. 1745137). CAS is supported by the NASA Headquarters Cryospheric Science Program. We 1194 acknowledge the use of data from CReSIS generated with support from the University of Kansas, NASA 1195 Operation IceBridge grant NNX16AH54G, NSF grants ACI-1443054, OPP-1739003, and IIS-1838230, Lilly 1196 Endowment Incorporated, and Indiana METACyt Initiative.

\section{References}

Abdalati, W., and Steffen, K.: Snowmelt on the Greenland Ice Sheet as derived from passive microwave satellite data, J. Climate, 10, 165-175, https://doi.org/10.1175/15200442(1997)010<0165:SOTGIS>2.0.CO;2, 1997.

Alley, R. B., Dupont, T. K., Parizek, B. R., Anandakrishnan, S.: Access of surface meltwater to beds of subfreezing glaciers: Preliminary insights, Ann. Glaciol., 40, 8-14, https://doi.org/10.3189/172756405781813483, 2005.

Ashcraft, I. and Long, D.: Comparison of methods for melt detection over Greenland using active and passive microwave measurements, Int. J. Remote Sens., 27, 2469-2488, https://doi.org/10.1080/01431160500534465, 2006.

Benson, C. S.: Stratigraphic studies in the snow and firn of the Greenland Ice Sheet, Ph.D. thesis, California Institute of Technology, 228 pp., 1960.

Bindschadler, R. A., Jezek, K. C., and Crawford, J.: Glaciological investigations using the synthetic aperture radar imaging system, Ann. Glaciol., 9, 11-19. https://doi.org/10.1017/S0260305500200694, 1987.

Brangers, I., Lievens, H., Miège, C., Demuzere, M., Brucker, L., and De Lannoy, G. J. M.: Sentinel-1 detects firn aquifers in the Greenland Ice Sheet, Geophys. Res. Lett., 47, e2019GL085192, https://doi.org/10.1029/2019GL085192, 2020.

Brodzik, M. J., Long, D. G., and Hardman, M. A.: SMAP Radiometer Twice-Daily rSIR-Enhanced EASEGrid 2.0 Brightness Temperatures, Version 1, NASA National Snow and Ice Data Center Distributed Active Archive Center,https://doi.org/10.5067/QZ3WJNOUZLFK, 2019.

Brodzik, M. J., Billingsley, B., Haran, T., Raup, B., and Savoie, M. H.: EASE-Grid 2.0: Incremental but significant improvements for Earth-gridded data sets, ISPRS Int. J. Geo-Inf., 1, 32-45, https://doi.org/10.3390/ijgi1010032, 2012. 
https://doi.org/10.5194/tc-2021-116

Preprint. Discussion started: 30 April 2021

(c) Author(s) 2021. CC BY 4.0 License.

Chu, W., Schroeder, D. M., and Siegfried, M. R.: Retrieval of englacial firn aquifer thickness from icepenetrating radar sounding in southeastern Greenland, Geophys. Res. Lett., 45, 11,770-11,778, https://doi.org/10.1029/2018GL079751, 2018.

1232

CReSIS: CReSIS radar depth sounder data, Digital Media, http://data.cresis.ku.edul, 2016.

1233

1234

1235

1236

1237

1238

1239

1240

1241

1242

1243

1244

1245

1246

1247

1248

1249

1250

1251

1252

1253

1254

1255

1256

1257

1258

1259

1260

1261

1262

1263

1264

1265

1266

1267

1268

1269

1270

1271

1272

1273

1274

1275

1276

1277

1278

1279

1280

1281

Colgan, W., Rajaram, H., Abdalati, W., McCutchan, C., Mottram, R., Moussavi, M. S., and Grigsby, S.: Observations, models, and mass balance implications: Glacier crevasses, Rev. Geophys., 54, 119-161, https://doi.org/10.1002/2015RG000504, 2016

Culberg, R., Schroeder, D.M. and Chu, W.: Extreme melt season ice layers reduce firn permeability across Greenland, Nat Commun, 12, 2336, https://doi.org/10.1038/s41467-021-22656-5, 2021

Culberg, R.: Refrozen melt layer location, density, and connectivity records from airborne radar sounding, Greenland, NSF Arctic Data Center, https://doi.org/10.18739/A2736M33W, 2021.

Cullather, R. I., Andrews, L. C., Croteau, M. J., Digirolamo, N. E., Hall, D. K., Lim, Y., Loomis, B. D., Shuman, C. A., and Nowicki, S. M. J.: Anomalous circulation in July 2019 resulting in mass loss on the Greenland Ice Sheet. Geophys. Res. Lett., 47, https://doi.org/10.1029/2020GL087263, 2020.

Das, S. B., Joughin, I., Behn, M. D., Howat, I. M., King, M. A., Lizarralde, D., Bhatia, M. P., Fracture propagation to the base of the Greenland Ice Sheet during supraglacial lake drainage, Science, 320, 778781, https://doi.org/10.1126/science.1153360, 2008.

Drinkwater, M. R., Long, D. G., and Bingham, A. W.: Greenland snow accumulation estimates from satellite radar scatterometer data, J. Geophys. Res. Atmos., 106, 33935-33950. https://doi.org/10.1029/2001JD900107, 2001.

Dunmire, D., Banwell, A. F., Lenaerts, J. T. M., and Datta, R. T.: Contrasting regional variability of buried meltwater extent over two years across the Greenland Ice Sheet, The Cryosphere Discuss, https://doi.org/10.5194/tc-2021-3, in review, 2021.

Early, D. S., and Long, D. G.: Image reconstruction and enhanced-resolution imaging from irregular samples, IEEE Trans. Geosci. Remote Sens. 39, 291-302, https://doi.org/10.1109/36.905237, 2001.

Echelmeyer, K., Clarke, T. S., and Harrison, W. D.: Surficial glaciology of Jakobshavn Isbræ, West Greenland 1. Surface morphology, J. Glaciol., 37, 368-382, https://doi.org/10.1017/S0022143000005803, 1991.

Entekhabi, D., et al.: The Soil Moisture Active Passive (SMAP) Mission, Proc. IEEE, 98, 704-716, https://doi.org/10.1109/JPROC.2010.2043918, 2010.

Fahnestock, M., Bindschadler, R., Kwok, R., and Jezek, K.: Greenland Ice Sheet surface properties and ice dynamics from ERS-1 SAR imagery. Science, 262, 1530-1534. https://doi.org/10.1126/science.262.5139.1530, 1993.

Forster, R. R., Box, J. E., Van Den Broeke, M. R., Miège, C., Burgess, E. W., Van Angelen, J. H., Lenaerts, J. T. M., Koenig, L. S., Paden, J., Lewis, C., Gogineni, S. P., Leuschen, C., and McConnell, J. R.: Extensive liquid meltwater storage in firn within the Greenland Ice Sheet, Nat. Geosci., 7, 95-98, https://doi.org/10.1038/ngeo2043, 2014.

Fountain, A. G., and Walder, J. S.: Water flow through temperate glaciers. Rev. of Geophys., 36, 299-328, https://doi.org/10.1029/97RG03579, 1998.

Freilich, M. H., Long, D. G., and Spencer, M. W.: SeaWinds: A scanning scatterometer for ADEOS-II science overview, Proc. IEEE, 1994, 960-963, https://doi.org/10.1109/IGARSS.1994.399313, 1994. 
https://doi.org/10.5194/tc-2021-116

Preprint. Discussion started: 30 April 2021

(c) Author(s) 2021. CC BY 4.0 License.

Franco, B., Fettweis, X., and Erpicum, M.: Future projections of the Greenland ice sheet energy balance driving the surface melt, The Cryosphere, 7, 1-18, https://doi.org/10.5194/tc-7-1-2013, 2013

Goward, S. N., Masek, J. G., Williams, D. L., Irons, J. R., and Thompson, R. J.: The Landsat 7 mission: Terrestrial research and applications for the 21st century. Remote Sensing of Environment, 78, 3-12. https://doi.org/10.1016/S0034-4257(01)00262-0, 2001.

Hall, D. K., and DiGirolamo, N.: Multilayer Greenland Ice Surface Temperature, Surface Albedo, and Water Vapor from MODIS, Version 1, NASA National Snow and Ice Data Center Distributed Active Archive Center, https://doi.org/10.5067/7THUWT9NMPDK, 2019.

Hall, D. K., Comiso, J. C., Digirolamo, N. E., Shuman, C. A., Key, J. R., and Koenig, L. S.: A satellite-derived climate-quality data record of the clear-sky surface temperature of the Greenland Ice Sheet, J. Clim., 25, 4785-4798, https://doi.org/10.1175/JCLI-D-11-00365.1, 2012.

Hanna, E., Navarro, F. J., Whitehouse, P. L., Zwally, H. J., Pattyn, F., Domingues, C. M., Fettweis, X., Ivins, E. R., Nicholls, R. J., Ritz, C., Smith, B., and Tulaczyk, S.L: Ice-sheet mass balance and climate change, Nature, 498, 51-59, https://doi.org/10.1038/nature12238, 2013.

Haran, T., Bohlander J., Scambos T., Painter, T., and Fahnestock, M.: MEaSUREs MODIS Boulder, Colorado USA. NASA National Snow and Ice Data Center Distributed Active Archive Center, https://doi.org/10.5067/9ZO79PHOTYE5, 2018.

Harper, J., Humphrey, N., Pfeffer, W. T., Brown, J., and Fettweis, X.: Greenland ice-sheet contribution to sea-level rise buffered by meltwater storage in firn, Nature, 491, 240-243, https://doi.org/10.1038/nature11566, 2012.

Hicks, B. R., and Long, D. G.: Inferring Greenland melt and refreeze severity from SeaWinds scatterometer data, Int. J. Remote Sensing, 32, 8053-8080, https://doi.org/10.1080/01431161.2010.532174, 2011.

Howat, I.: MEaSUREs Greenland Ice Mapping Project (GIMP) Land Ice and Ocean Classification Mask, Version 1, NASA National Snow and Ice Data Center Distributed Active Archive Center, https://doi.org/10.5067/B8X58MQBFUPA, 2017.

Howat, I., Negrete, A., and Smith, B.: MEaSUREs Greenland Ice Mapping Project (GIMP) Digital Elevation Model, Version 1, NASA National Snow and Ice Data Center Distributed Active Archive Center, doi: https://doi.org/10.5067/NV34YUIXLP9W, 2015.

Howat, I., Negrete, A., and Smith, B.: The Greenland Ice Mapping Project (GIMP) land classification and surface elevation datasets, The Cryosphere, 8, 1509-1518, https://doi.org/10.5194/tc-8-1509-2014, 2014.

Humphrey, N. F., Harper, J. T., and Pfeffer, W. T.: Thermal tracking of meltwater retention in Greenland's accumulation area, J. Geophys. Res., 117, https://doi.org/10.1029/2011JF002083, 2012.

Jezek, K. C., Drinkwater M. R., Crawford, J. P., Bindshandler, R., and Kwok, R.: Analysis of synthetic aperture radar data collected over the southwestern Greenland Ice Sheet. J. of Glaciol, 39, 119-132, https://doi.org/10.1017/S002214300001577X, 1993.

Jezek, K. C., Gogineni, P., and Shanableh, M.: Radar measurements of melt zones on the Greenland Ice Sheet, Geophys. Res. Lett., 21, 33-36, https://doi.org/10.1029/93GL03377, 1994.

Jezek, K. C., Johnson, J. T., Drinkwater, M. R., Macelloni, G., Tsang, L., Aksoy, M., and Durand M.: Radiometric approach for estimating relative changes in intraglacier average temperature, IEEE Trans. Geosci. Remote Sens., 53, 134-143, https://doi.org/10.1109/TGRS.2014.2319265, 2015. 
https://doi.org/10.5194/tc-2021-116

Preprint. Discussion started: 30 April 2021

(c) Author(s) 2021. CC BY 4.0 License.

1339

Jezek, K. C., Johnson J. T., Tan S., Tsang L., Andrews, M. J., Brogioni, M., Macelloni, G., Durand, M., Chen, C. C., Belgiovane, D. J., Duan, Y., Yardim, C., Li, H., Bringer, A., Leuski, V., and Aksoy, M.: 5002000-MHz brightness temperature spectra of the northwestern Greenland Ice Sheet, IEEE Trans. Geosci. Remote Sens., 56, 1485-1496, https://doi.org/10.1109/TGRS.2017.2764381, 2018.

Jones, W. L., Schroeder, L. C., Boggs, D. H., Bracalente, E. M., Brown, R. A., Dome, G. J., Pierson, W. J., and Wentz, F. J.: The SEASAT-A satellite scatterometer: The geophysical evaluation of remotely sensed wind vectors over the ocean: J. Geophys. Res. Oceans, 87, 3297-3317, https://doi.org/10.1029/JC087iC05p03297, 1982.

Joughin, I., Das, S. B., Flowers, G .E., Behn, M. D., Alley, R. B., King, M. A., Smith, B. E., Bamber, J. L., van den Broeke, M. R., and Van Angelen, J. H.: Influence of ice-sheet geometry and supraglacial lakes on seasonal ice-flow variability, The Cryosphere, 7, 1185-1192, https://doi.org/10.5194/tc-7-1185-2013, 2013.

Joughin, I., Das, S. B., King, M. A., Smith, B. E., Howat, I. M., and Moon, T.: Seasonal speedup along the western flank of the Greenland Ice Sheet, Science, 320, 781-783, https://doi.org/10.1126/science.1153288, 2008.

Kerr, Y. H., Waldteufel, P., Wigneron, J., Martinuzzi, J., Font, J., and Berger, M.: Soil moisture retrieval from space: The Soil Moisture and Ocean Salinity (SMOS) mission, IEEE Trans. Geosci. Remote Sens., 39, 1729-1735, https://doi.org/10.1109/36.942551, 2001.

Koenig, L. S., Miège, C., Forster, R. R., and Brucker, L.: Initial in situ measurements of perennial meltwater storage in the Greenland firn aquifer, Geophys. Res. Lett., 41, 81-85, https://doi.org/10.1002/2013GL058083, 2014.

Kuipers Munneke, P. K., Ligtenberg, S. R. M., Van Den Broeke, M. R., Van Angelen, J. H., and Forster, R. R.: Explaining the presence of perennial liquid water bodies in the firn of the Greenland Ice Sheet, Geophys. Res. Lett., 41, 476-483, https://doi.org/10.1002/2013GL058389, 2014.

Le Vine, D. M., Lagerloef, G. S. E., and Torrusio, S. E.: Aquarius and remote sensing of sea surface salinity from space, Proc. IEEE, 98, 688-703, https://doi.org/10.1109/JPROC.2010.2040550, 2010.

Lewis, C., Gogineni, S., Rodriguez-Morales, F., Panzer, B., Stumpf, T., Paden, J., and Leuschen, C.: Airborne fine-resolution UHF radar: An approach to the study of englacial reflections, firn compaction and ice attenuation rates, J. Glaciology, 61, 89-100. https://doi.org/10.3189/2015JoG14J089, 2015.

Long, D. G., Brodzik, M. J., and Hardman M. A.: Enhanced-resolution SMAP brightness temperature image products, IEEE Trans. Geosci. Remote Sens., 57, 4151-4163, https://doi.org/10.1109/TGRS.2018.2889427, 2019.

Long, D. G., and Brodzik, M. J.: Optimum image formation for spaceborne microwave radiometer products, IEEE Trans. Geosci. Remote Sens., 54, 2763-2779. https://doi.org/10.1109/TGRS.2015.2505677, 2016.

Long, D. G., and Daum, D. L.: Spatial resolution enhancement of SSM/I data, IEEE Trans. Geosci. Remote Sens., 36, 407-417, https://doi.org/10.1109/36.662726, 1998.

Long, D. G., and Drinkwater, M. R.: Greenland Ice Sheet surface properties observed by the Seasat-A

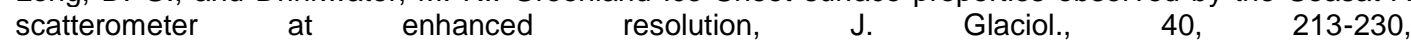
https://doi.org/10.1017/S0022143000007310, 1994.

Long, D. G., Hardin, P. J., and Whiting, P. T.: Resolution enhancement of spaceborne scatterometer data, IEEE Trans. Geosci. Remote Sens., 31, 700-715, https://doi.org/10.1109/36.225536, 1993. 
https://doi.org/10.5194/tc-2021-116

Preprint. Discussion started: 30 April 2021

(c) Author(s) 2021. CC BY 4.0 License.

MacFerrin, M., Machguth, H., van As, D., Charalampidis, C., Stevens, C. M., Heilig, A., Vandecrux, B.,

Langen, P. L., Mottram, R., Fettweis, X., van den Broeke, M. R., Pfeffer, W. T., Moussavi, M. S., and Abdalati, W.: Rapid expansion of Greenland's low-permeability ice slabs. Nature, 573, 403-407, https://doi.org/10.1038/s41586-019-1550-3, 2019.

Machguth, H. McFerrin M., van As, D., Box, J. E., Charalampidis, C., Colgan., W., Fausto, R. S., Harro, A J., Mosley-Thompson, E., and van de Wal, R. S. W.: Greenland meltwater storage in firn limited by nearsurface ice formation. Nat. Clim. Chang. 6, 390-393, https://doi.org/10.1038/nclimate2899, 2016.

Mätzler, C., and Hüppi, R.: Review of signature studies for microwave remote sensing of snowpacks, Adv. in Space Res., 9, 253-265, https://doi.org/10.1016/0273-1177(89)90493-6, 1989.

Miège, C., Forster, R. R., Brucker, L., Koenig, L. S., Solomon, D.K., Paden, J. D., Box, J. E., Burgess, E. W., Miller, J. Z., McNerney, L., Brautigam, N., Fausto, R. S., and Gogineni, S.: Spatial extent and temporal variability of Greenland firn aquifers detected by ground and airborne radars, J. Geophys. Res. Earth, 121, 2381-2398, https://doi.org/10.1002/2016JF003869, 2016.

Miles, K. E., Willis, I. C., Benedek, C. L., Williamson, A. G., and Tedesco, M.: Toward monitoring surface and subsurface lakes on the Greenland Ice Sheet Using Sentinel-1 SAR and Landsat-8 OLI imagery, Frontiers in Earth Science, 5, 58, https://doi.org/https://doi.org/10.3389/feart.2017.00058, 2017.

Miller, J. Z., Long, D. G., Jezek, K. C., Johnson, J. T., Brodzik, M. J., Shuman, C. A., Koenig, L. S., and Scambos, T. A.: Brief communication: Mapping Greenland's perennial firn aquifers using enhancedresolution L-band brightness temperature image time series, The Cryosphere, 14, 2809-2817, https://doi.org/10.5194/tc-14-2809-2020, 2020.

Miller, J. Z.: Mapping Greenland's firn aquifers from space using active and passive satellite microwave remote sensing, Ph.D. thesis, Department of Geography, University of Utah, 135 pp., 2019.

Miller, O. L., Solomon, D. K., Miège, C., Koenig, L. S., Forster, R. R., Montgomery, L. N., Schmerr, N., Ligtenberg, S. R. M., Legchenko, A., and Brucker, L.: Hydraulic conductivity of a firn aquifer in southeast Greenland, Front. Earth Sci., 5, https://doi.org/10.3389/feart.2017.00038, 2017.

Montgomery, L. N., Schmerr, N., Burdick, S., Forster, R. R., Koenig, L., Legchenko, A., Ligtenberg, S., Miège, C., Miller, O. L., and Solomon, D. K.: Investigation of firn aquifer structure in southeastern Greenland using active source seismology, Front. Earth Sci., 5, https://doi.org/10.3389/feart.2017.00010, 2017.

Moon, T., Joughin, I., Smith, B., Broeke, M. R., Berg, W. J., Noël, B., and Usher, M.: Distinct patterns of seasonal Greenland glacier velocity, Geophys. Res. Lett., 41, 7209-7216, https://doi.org/10.1002/2014GL061836, 2014.

Mote, T. L., and Andersen, M. R.: Variations in snowpack melt on the Greenland lce Sheet based on passive microwave measurements, J. Glaciology, 41, 51-60, https://doi.org/10.1017/S0022143000017755, 1995.

Noël, B., van Kampenhout, L., Lenaerts, J. T. M., van de Berg, W. J, and van den Broeke, M. R.: A 21st century warming threshold for sustained Greenland Ice Sheet mass loss, Geophys. Res. Lett.,, 48(5), https://doi.org/10.1029/2020GL090471, 2021.

Noël, B., van de Berg, Willem Jan, Lhermitte, S. L. M., and van den Broeke, Michiel R.: Rapid ablation zone expansion amplifies north Greenland mass loss, Sci. Adv, 5, eaaw0123, https://doi.org/10.1126/sciadv.aaw0123, 2019.

Noël, B., van de Berg, W. J., van Wessem, J. M., van Meijgaard, E., van As, D., Lenaerts, J. T. M., Lhermitte, S., Kuipers Munneke, P., Smeets, C. J. P. P., van Ulft, L. H., van de Wal, R. S. W., and van den Broeke, M. R.: Modelling the climate and surface mass balance of polar ice sheets using RACMO2 - Part 1: Greenland (1958-2016), The Cryosphere, 12, 811-831, https://doi.org/10.5194/tc-12-811-2018, 2018. 
https://doi.org/10.5194/tc-2021-116

Preprint. Discussion started: 30 April 2021

(c) Author(s) 2021. CC BY 4.0 License. N. E., \& Neumann, G.: The extreme melt across the Greenland Ice Sheet in 2012, Geophys. Res. Lett.,, 39, https://doi.org/10.1029/2012GL053611, 2003

Nghiem, S. V., Hall, D. K., Mote, T. L., Tedesco, M., Albert, M. R., Keegan, K., Shuman, C. A., DiGirolamo, N.E., and Neumann, G.: The extreme melt across the Greenland Ice Sheet in 2012, Geophys. Res. Lett., 39, L20502, https://doi.org/10.1029/2012GL053611, 2012.

Paden, J., Li, J., Leuschen C., F. Rodriguez-Morales, F., and Hale, R.: IceBridge Accumulation Radar L1B Geolocated Radar Echo Strength Profiles, Version 2, NASA National Snow and Ice Data Center Distributed Active Archive Center, https://doi.org/10.5067/0ZY1XYHNIQNY, 2014, updated 2018.

Partington, K. C.: Discrimination of glacier facies using multi-temporal SAR data. J. Glaciol., 44, $42-53$. https://doi.org/10.3189/S0022143000002331, 1998.

Pfeffer, W. T., Meier, M. F., and Illangasekare, T. H.: Retention of Greenland runoff by refreezing: Implications for projected future sea level change. J. Geophys. Res. Oceans, 96, 22117-22124, https://doi.org/10.1029/91JC0250, 1991.

Pfeffer, W. T., and Humphrey, N.F.: Determination of timing and location of water movement and ice-layer formation by temperature measurements in sub-freezing snow, J. Glaciol., 42, 292-304, https://doi.org/10.1017/S0022143000004159, 1996.

Piepmeier, J. R., et al.: SMAP L-band microwave radiometer: Instrument design and first year on orbit. IEEE Trans. Geosci. Remote Sens, 55, 1954-1966, https://doi.org/10.1109/TGRS.2016.2631978, 2017.

Poinar, K., Joughin, I., Lilien, D., Brucker, L., Kehrl, L., and Nowicki, S.: Drainage of southeast Greenland firn aquifer water through crevasses to the bed. Front. Earth Sci., https://doi.org/10.3389/feart.2017.00005, 2017.

Poinar, K., Dow, C. F., and Andrews, L. C.: Long-term support of an active subglacial hydrologic system in southeast Greenland by firn aquifers. Geophys. Res. Lett., 46, 4772-4781, https://doi.org/10.1029/2019GL082786, 2019.

Rignot, E.: Backscatter model for the unusual radar properties of the Greenland Ice Sheet, J. Geophys. Res. Planets, 100, 9389-9400, https://doi.org/10.1029/95JE00485, 1995.

Rignot, E. J., Ostro, S. J., Van Zyl, J., and Jezek, K. C.: Unusual radar echoes from the Greenland Ice Sheet, Science, 261, 1710-1713, https://doi.org/10.1126/science.261.5129.171, 1993.

Rodriguez-Morales, F., et al.: Advanced multi-frequency radar instrumentation for polar research, IEEE Trans. Geosci. Remote Sens., 52, 2824-2842, https://doi.org/10.1109/TGRS.2013.2266415, (2014).

Schröder L., Neckel N., Zindler R., Humbert A.: Perennial supraglacial lakes in northeast Greenland observed by polarimetric SAR, Remote Sensing, 12, 2798, https://doi.org/10.3390/rs12172798 (2020).

Shuman, C. A., Hall, D. K., DiGirolamo, N. E., Mefford T. K., and Schnaubelt, M. J.: Comparison of nearsurface air temperatures and MODIS ice-surface temperatures at Summit, Greenland (2008-2013), J. Appl. Meteor. Climatol., 53, 2171-2180, https://doi.org/10.1175/JAMC-D-14-0023.1, 2014.

Steffen, K., Nghiem, S. V., Huff, R., and Neumann, G.: The melt anomaly of 2002 on the Greenland Ice Sheet from active and passive microwave satellite observations. Geophys. Res. Lett., 31, L2040, https://doi.org/10.1029/2004GL020444, 2004. 
https://doi.org/10.5194/tc-2021-116

Preprint. Discussion started: 30 April 2021

(c) Author(s) 2021. CC BY 4.0 License.

1503 Stevens, L. A., Behn, M. D., McGuire, J. J., Das, S. B., Joughin, I., Herring, T., Shean, D. E., and King, M. 1504 A.: Greenland supraglacial lake drainages triggered by hydrologically induced basal slip, Nature, 522, 73-

76. https://doi.org/10.1038/nature14480, 2015

Swift, C. T., Hayes, P. S., Herd, J. S., Jones, W. L., and Delnore, V. E.: Airborne microwave measurements of the southern Greenland Ice Sheet, J. Geophys. Res. Solid Earth, 90, 1983-1994, https://doi.org/10.1029/JB090iB02p01983, 1985.

Tedesco, M., and Fettweis, X.: Unprecedented atmospheric conditions (1948-2019) drive the 2019 exceptional melting season over the Greenland Ice Sheet, The Cryosphere, 14, 1209-1223, https://doi.org/10.5194/tc-14-1209-2020, 2020.

Tedesco, M., Mote, T., Fettweis, X., Hanna, E., Jeyaratnam, J., Booth, J. F., Datta, R., and Briggs, K.: Arctic cut-off high drives the poleward shift of a new Greenland melting record, Nature Commun., 7, 11723-11723, https://doi.org/10.1038/ncomms11723 1985, 2016.

Tedesco, M., Fettweis, X., van den Broeke, M. R., van de Wal, R. S. W., Smeets, C. J. P. P., van de Berg, W. J., Serreze, M. C., and Box, J. E.: The role of albedo and accumulation in the 2010 melting record in Greenland, Environ. Res. Lett, 6, 014005, https://doi.org/10.1088/1748-9326/6/1/014005, 2011.

Tedesco, M., Serreze, M., and Fettweis, X.: Diagnosing the extreme surface melt event over southwestern Greenland in 2007. The Cryosphere, 2, 159-166. https://doi.org/10.5194/tc-2-159-2008, 2008.

Tiuri, M. E., Sihvola, A. H., Nyfors, E. G., Hallikaiken, M. T.: The complex dielectric constant of snow at microwave frequencies, IEEE J. Ocean Eng, 9, 377-382, https://doi.org/10.1109/JOE.1984.1145645, 1984.

Tsai, W., Nghiem, S. V., Van Zyl, J. J.: SeaWinds scatterometer on QuikSCAT mission and the emerging land and ocean applications, Proc. SPIE 4152, https://doi.org/10.1117/12.410586, 2000

Trusel, L. D., Das, S. B., Osman, M. B., Evans, M. J., Smith, B. E., Fettweis, X., McConnell, J. R., Noël, B. P. Y., and van den Broeke, M. R.: Nonlinear rise in Greenland runoff in response to post-industrial Arctic warming, Nature, 564, 104-108, https://doi.org/10.1038/s41586-018-0752-4, 2018.

Turton, J. V., Hochreuther, P., Reimann, N., and Blau, M. T.: The distribution and evolution of supraglacial lakes on the $79^{\circ} \mathrm{N}$ Glacier (northeast Greenland) and interannual climatic controls, The Cryosphere Discuss, https://doi.org/10.5194/tc-2021-45, in review, 2021.

Ulaby, F. T., Long, D. G., Blackwell, W. J., Elachi, C., Fung, A. K., Ruf, C., Sarabandi, C., Zebker, H. A., Van Zyl, J.: Microwave radar and radiometric remote sensing, University of Michigan Press, Ann Arbor, 2014

van den Broeke, M. R., Enderlin, E. M., Howat, I. M., Kuipers Munneke, P., Noël, B. P. Y., van de Berg, W. J., van Meijgaard, E., and Wouters, B.: On the recent contribution of the Greenland ice sheet to sea level change, The Cryosphere, 10, 1933-1946, https://doi.org/10.5194/tc-10-1933-2016, 2016.

van der Veen, C. J.: Fracture propagation as means of rapidly transferring surface meltwater to the base of glaciers, Geophys. Res. Lett., 34, L01501, https://doi.org/10.1029/2006GL028385, 2005.

Wessel, P., and Smith, W. H. F.: A global, self-consistent, hierarchical, high-resolution shoreline database, J. Geophys. Res., 101, 8741-8743, https://doi.org/10.1029/96JB00104, 1996.

Zabel, I. H. H., Jezek, K. C., Baggeroer, P. A., and Gogineni, S. P: Ground-based radar observations of snow stratigraphy and melt processes in the percolation facies of the Greenland Ice Sheet, Ann. Glaciol., 21, 40-44. https://doi.org/10.3189/S0260305500015573, 1995. 
https://doi.org/10.5194/tc-2021-116

Preprint. Discussion started: 30 April 2021

(c) Author(s) 2021. CC BY 4.0 License.

Zwally, H. J., Abdalati, W., Herring, T., Larson, K., Saba, J., and Steffen, K.: Surface melt-induced acceleration of Greenland Ice Sheet flow, Science, 297, 218-222, https://doi.org/10.1126/science.1072708, 2002.

1561

1562

1563

Zwally, J. H.: Microwave emissivity and accumulation rate of polar firn, J. Glaciol., 18, 195-215, https://doi.org/10.1017/S0022143000021304, 1977. 